\title{
Capturing differences in conservatism following earnings restatements: further evidence from Tehran Stock Exchange
}

\author{
Shayan Farhangdoust \\ Department of Accounting, Imamreza International University of Mashhad, \\ Mashhad, Iran, and \\ Lida Sayadi \\ Department of Accounting, Shiraz University, Shiraz, Iran
}

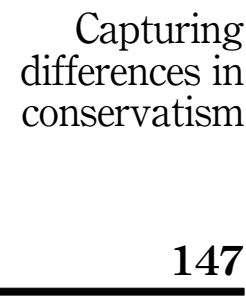

Received 20 September 2019 Revised 20 December 2019 31 January 2020 18 March 2020 Accepted 24 March 2020

\begin{abstract}
Purpose - The present study seeks to shed further light on the effectiveness of Basu (1997) and Khan and Watts' (2009) differential timeliness metrics in detecting predictable differences in conservatism following corrections of restated earnings.

Design/methodology/approach - Using cross-sectional and time-series analyses for companies listed on the Tehran Stock Exchange during 2009-2013, the results indicate lower conservatism for restating firms as compared to their counterparts during prerestatement period.

Findings - Using cross-sectional and time-series analyses for companies listed on the Tehran Stock Exchange during 2009-2013, the results indicate lower conservatism for restating firms as compared to their counterparts during prerestatement period. In contrast, our findings are indicative of higher conservatism among these restating firms during the years of restatements. Moreover, the time-series approach captures a higher conservatism for the restating firms during restatement years than prerestatement periods. Overall, these results provide insight into the usefulness of the metrics used in the restatement setting.

Originality/value - Similar to recent papers, the present study seeks to shed further light on the ability of Basu-based coupled with Khan-Watts-based measures of conservatism to detect situations in which companies' earnings are known to be significantly restated.
\end{abstract}

Keywords Conservatism, Differential timeliness, Earnings restatements, Tehran Stock Exchange

Paper type Research paper

\section{Introduction}

Financial reporting is regarded as a vital mechanism through which managers establish communication with investors. This mechanism mitigates information asymmetry among managers and investors and also aids investors in preventing adverse selection. Furthermore, the credibility of financial reports is the primary concern among investors whose decisions are significantly dependent on these reports. In this regard, the concept of conservatism as reflected in the adage "anticipate no profits but anticipate all losses" improves the credibility of financial reports since it reduces the managers' ability to manipulate and overstate financial performance. To date, some academic studies have put several interpretations regarding accounting conservatism. Basu (1997), for instance, suggests that conservatism is attributable to accountant's tendency in recognizing good

(C) Shayan Farhangdoust and Lida Sayadi. Published in Asian Journal of Accounting Research. Published by Emerald Publishing Limited. This article is published under the Creative Commons Attribution (CC BY 4.0) licence. Anyone may reproduce, distribute, translate and create derivative works of this article (for both commercial and non-commercial purposes), subject to full attribution to the original publication and authors. The full terms of this licence may be seen at http://creativecommons.org/licences/by/4.0/ legalcode

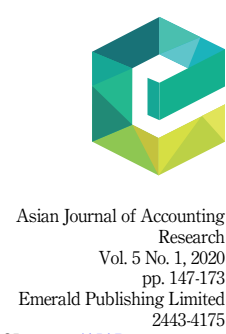

DOI 10.1108/AJAR-09-2019-0072 
AJAR 5,1

news in a timelier fashion than bad news. Further, he argues that unrealized losses are supposed to be recognized more quickly than unrealized gains, affecting the timeliness and persistence of earnings. Altogether, his paper interprets accounting conservatism as asymmetric threshold for gains versus losses. There are some alternative reasons behind the occurrence of conservatism, namely contracting, shareholder litigation, taxation and accounting regulation, among which contracting and shareholder litigation explanations are of highest importance (Watts, 2003). It is generally argued that the systematic understatement of the entity's net assets (equity) is purported to be the consequence of conservative accounting (Givoly et al., 2007). Prior literature also suggests that asset understatement may be caused by two distinctive reporting aspects, namely "conservative accounting methods" (e.g. the development of R\&D operations or the use of accelerated depreciation or LIFO) and the asymmetric timeliness of recognizing gains and losses (e.g. the application of the lower-of-cost-or-market rule) (Givoly et al. 2007; Watts, 2003). These features of reporting are called "unconditional conservatism" and "conditional conservatism," respectively. Ball et al. (2011) contend that conditional conservatism is indicative of asymmetric timely loss recognition. Specifically, while previous view of conservatism implies asymmetric response to new information (i.e. the selection of lower book value of stockholder's equity), the contemporary issue regarding the concept of conditional conservatism suggests the timelier recognition of bad news about firm value than good news (Ball et al., 2011). Among all restating firms, those that have overstated earnings in their original reports generate more concerns about the credibility of their financial reporting since there is greater likelihood of aggressive reporting by the managers of these firms for their own private benefits. Therefore, investors may demand a higher level of conservatism for overstating firms subsequent to their overstatement disclosures (Huang and Zhang, 2009).

To our knowledge, several empirical studies have investigated the way in which conservatism could be quantified and introduced several measures. Feltham and Ohlson (1995), for instance, suggest the expected market-to-book ratio and other financial ratios which have been widely used in several researches (e.g. Stober, 1996; Joos and Lang, 1994; Ahmed et al., 2000; Beaver and Ryan, 2000; Givoly and Hayn; 2000; Ball et al., 2011; Ettredge et al., 2012). However, the widespread use of Basu's measure of differential timeliness to gauge conservatism provided us with an incentive to examine its capability to capture the conservatism differences following earnings overstatements. Specifically, consistent with Ettredge et al. (2012), the evaluation of the power and reliability of Basu's conservatism metric has been the focal issue in this paper. Moreover, Khan and Watts (2009) also estimate a firmyear measure (C-score) to capture cross-sectional and intertemporal variation in asymmetric earnings timeliness. Khan and Watts (2009) argue that both industry-year measure and individual firm measure are accompanied by some limitations (i.e. the assumption of homogenous firms in the industry and the assumption that the firm's operating characteristics are stationary). Following the seminal work by Basu (1997), Khan and Watts (2009), and subsequent empirical studies (Dietrich et al., 2007; Givoly et al., 2007; Patatoukas and Thomas, 2011; Ettredge et al., 2012), the present study attempts to capture discernible differences in conservatism following earnings overstatements in an emerging market like the Tehran Stock Exchange (TSE).

Based on Generally Accepted Accounting Principles (GAAP), the reasons for the restatements of financial statements are twofold: the changes in accounting principles and procedures and/or the correction of accounting errors. The restated financial statements provide new information for the market. From investors' point of view, the signals communicated by restatement announcements are not specifically attributable to a firm's past performance; in other words, they believe that the occurrence of financial restatements could also imply increased potential for future financial reporting problems, including a loss of confidence in the competence of management as well as the quality of a firm's earnings. 
Indeed, the restated financial statements communicate explicit signals regarding the unreliability of financial statements as well as their lower quality. Therefore, subsequent to restatements, investors' demands regarding future free cash flows and the expected rate of return would change (Xia, 2006). The occurrence of financial restatements has resulted in different consequences. For instance, Iran Khodro Industrial Group (known as IKCO) as one of the most prominent automobile manufacturers in Iran, despite being highly profitable, failed to pay cash dividends in fiscal year 2009, due in part to the occurrence of financial restatements and annual adjustments. The stock market value of this firm had been approximately ten percent of TSE's total value prior to this date. Subsequently, the stockholders brought this incident into a burning question (Aghaei et al., 2013).

Following Ettredge et al. (2012), we attempt to contribute to accounting literature by providing further evidence regarding the effectiveness of Basu-based and C-score measures in explaining the differences in conservatism following earnings overstatements. Companies' earnings are expected to be less conservative during the years of overstatements when Basu's (1997) differential timeliness (DT) metric is effective. Considering Basu's DT metric, we expect lower conservatism for restating firms in comparison to nonrestating firms during preoverstatement period. In addition, it is expected that the restating firms show more conservatism than other firms during the years of overstatements. It is noteworthy that we employ both cross-sectional and time-series analyses to test previously mentioned metrics.

The paper's findings suggest that conservatism metric is significantly lower for restating firms as compared to nonrestating firms during prerestatement period. In other words, the present paper suggests that restating firms are more conservative than their counterparts when there is no earnings restatement reported by sample firms. It is also found that restating firms are more conservative than control firms in periods leading up to earnings restatement. Finally, the time-series approach indicates that the restating firms are more conservative than their counterparts during the restatement years, as compared to prerestatement periods. These results provide insight into the usefulness of the metrics used in the restatement setting.

Our paper is primarily incentivized by the following motivations. First, prior domestic literature in Iran suggests that approximately $54 \%$ of listed companies on the Tehran Stock Exchange (TSE) have disclosed annual restatements in their financial reports over the last decade (Saei et al., 2013; Salehi et al., 2017). Comparing this figure with its corresponding ratio in international context implies a significant difference as the ratio of restating firms to total statistical population of foreign studies is practically 3-7\% [1] (GAO, 2002; Hay and Sandefur, 2007). According to domestic studies, firm's profitability, financial leverage, management tenure, auditor tenure and the size of audit firm are among the most important factors associated with annual restatements in TSE (Saei et al., 2013; Salehi et al., 2017). For instance, Aghaei et al. (2013) indicate that the occurrence of financial restatements and annual adjustments in one of the most profitable and prominent automobile manufacturers in Iran, known as Iran Khodro Industrial Group (IKCO), has led to the failure to pay cash dividends in fiscal year 2009. Prior to this date, the stock market value of IKCO had been approximately $10 \%$ of TSE total value. Second, the present study is remarkable and unique in that it focuses on a specific transition market (i.e. the TSE) where there are significant differences in socioeconomic, political and cultural factors with those of Western or European developed markets: 1) prior to the current century, the ownership structure of listed companies on the TSE had been significantly focused and governmental, involving the Social Security Investment Company, creditor banks, Bonyad foundation groups and other state-owned institutions as major shareholders. However, the enactment of the Iranian Government's fiveyear privatization plans in 2000 has led to the substantial transfer of ownership structure from the government sector to the private sector and, consequently, more diffuse ownership structure. This incident has also caused some sort of information asymmetry between the

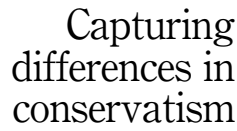


AJAR 5,1

agents and principals (Davani, 2003; Bagherpour et al., 2014); 2) the considerable involvement of petrochemical industry in the TSE; 3 ) the Government in Iran exerts considerable influence on setting accounting standards and tax laws, and the quality of financial reporting and disclosure is still poor. Therefore, Iran's current legal system is regarded as a code-law system and the TSE is considered as a weak equity market as compared to those markets in common-law countries. Under such legal system, corporate managers face with a choice between internal financing and bank debt financing and are more incentivized to report higher quality earnings (manipulate earnings) when they have higher private debts than public ones (Ghosh and Moon, 2010; GarcíaTeruel et al., 2014; Salehi et al., 2018). Taken together, since the sample used in this study differs substantially from the sample used by prior research studies, new insights and contributions are provided in the relationship between conservatism and earnings restatements.

The present study proceeds as follows. Section 2 reviews the related literature, offers an underpinning theoretical framework and presents our hypotheses. Section 3 discusses our empirical methodology. Section 4 presents descriptive statistics and main empirical results. Finally, Section 5 concludes the paper.

\section{Theoretical framework, literature review and hypothesis development \\ 2.1 Conservative accounting vis-à-vis earnings restatements}

The tsunami of accounting scandals, including Enron and WorldCom in the United States or Parmalat in Europe, at the beginning of the millennium is generally attributed to the quality of financial reporting. More specifically, the financial statements (balance sheet and income statement, primarily) lie at the heart of financial reporting process and have recently attracted a large body of research. Moreover, conservatism is regarded as a qualitative feature of financial reporting. Higher conservatism leads to quality information (Ball, 2009). The generic term "earnings management" is applied to intentional and unintentional intervention of managers in the reporting of their own financial performance and may include a different range of practices such as ethical (e.g. structuring transactions or to book losses in years with higher profits), violation of accepted standards of disclosure (e.g. giving year-end quantity discounts to major customers), negligent or grossly negligent financial reporting and fraudulent financial reporting (Ball, 2009). Some anecdotal evidence has also provided preliminary insight into explicit contractual arrangements, such as bonus plans and debt covenant as the incentives of earnings manipulation (Watts and Zimmerman, 1986; Dechow and Skinner, 2000; Richardson et al., 2002).

Earnings and net assets are most likely to be recognized with lower levels of bias under conservative accounting and in the context of investment growth. Prior literature suggests that this is not fully perceived by analysts when explaining their optimistic earning forecasts. Managers are often obliged to attain at the very least analysts' earning forecast. This may provide analysts with an incentive to modify their forecasts under conservative accounting. The number of firms issuing earning restatements has increased dramatically since the late 1990s and has been a focal issue in much of the research studies conducted so far. For instance, the US Treasury Department commissioned a study to investigate the increase in the restatement activity of public companies over the decade from 1997 to 2006 . The results suggested a significant increase in the number of items restated (up to 17 items) in the financial statements.

\subsection{Possible drivers of restatements}

Empirical evidence on restatement causes will benefit academics as well, who have made implicit or explicit assumptions about the causes of restatements. A broad range of potential motivations for the alleged financial restatements has been proposed such as: a lack of clarity 
in the standard and/or the proliferations of the accounting literature because of the lack of clarity in the original standard, the overly conservative nature of auditors, Securities and Exchange Commission (SEC), Public Company Accounting Oversight Board (PCAOB), the implementation of SOX Section 404 internal control reviews and the internal control error, which fails to detect material misstatements. It is also believed that the materiality threshold as required by Staff Accounting Bulletin (SAB) has a bearing on the increased level of restatements (Plumlee and Yohn, 2010). Accounting errors disclosed in financial restatements impair investors' confidence and, in consequence, lead to more conservative earnings. The occurrence of restatements is most likely to bring about some changes to financial statements suggesting the level of conservatism (Ettredge et al., 2009). Enhancing the quality of financial statements should be firms' first priority and a more direct way to restore financial statement credibility subsequent to the occurrence of restatements. Restating firms vis-à-vis nonrestating firms tend to adopt a more conservative accounting reporting strategy to restore their financial report reputation (Chang et al., 2011).

Based on the preceding discussions, what follows is a succinct review of explanations for the occurrence of financial restatements suggested in accounting literature. These explanations are broadly categorized into four groups.

2.2.1 Restatements related to the restating firm and its underlying features. Prior studies have suggested that firms' internal control weaknesses (Plumlee and Yohn, 2010); the lack and/or inefficiency of the firm's audit committee (Wu, 2002; Turner et al., 2001; Kinney and McDaniel, 1989); the poor profitability or growth of the firm; the higher financial leverage (Wu, 2002; Defond and Jiamblavo, 1991; Kinney and McDaniel, 1989); and finally, the negative cash inflows from firm's operations are among the most important reasons leading to restatement of financial accounts. Having an appropriate internal control system is an essential factor for financial reporting purposes (Turner and Weirich, 2006). Some preliminary academic works such as Ge and Mcvey (2005) argue that the existence of material weaknesses in internal control system can broaden the earnings management extent across all organizational levels and also contribute substantially to fraudulent financial reporting as well as the occurrence of material misstatements. Therefore, implementing a quality internal control system can be a prohibitory action regarding the occurrence of accounting restatements. Furthermore, a stream of research suggests that companies with higher reputation scores are less likely to misstate their financial statements (Cao et al., 2012). A negative significant relationship between firm size and financial restatements has also been suggested by previous studies.

2.2.2 Restatements related to management and corporate governance mechanisms. Based on prior research, the financial expertise of chief financial officers (CFOs) (Aier et al., 2005); diffuse ownership of firms (Defond and Jiamblavo, 1991); managers' conservative attitudes (Hay and Sandefur, 2007); capital market pressures acting as a motivating factor for companies to adopt aggressive accounting policies (Richardson et al., 2002); and managers' demand for meeting or beating industry benchmarks and the income or sale estimations of market analysts are contributory factors in the increased levels of financial restatements. Moreover, the increasing stock-based incentives and the resultant earnings management or manipulation by managers to achieve higher levels of compensation may also result in financial restatements

2.2.3 Restatements related to accounting standards. Accounting literature is indicative of various standard-related factors behind the occurrence of restatements, including the proliferation of accounting rules and implementation guidance (also ambiguous accounting standards and financial reporting rules), the application of the Sarbanes-Oxley Act (SOX) 404 requirements, accounting complexity and transaction complexity (Patel and Zeckhauser, 1999; Turner and Weirich, 2006; Hay and Sandfur, 2007; Plumlee and Yohn, 2010). Dzinkowski (2007) and others suggest that companies seek to find the paragraphs that apply 
AJAR 5,1

to the transaction of interest as they sift through the thousands of pages of accounting standards. They argue that the SEC and FASB periodically change the interpretation of the standards without adequate announcements. Plumlee and Yohn (2010) indicate that 37\% of restatements during their four-year sample period (2003-2006) are related to the use of judgment in applying the accounting standards. Furthermore, their results show that restatements attributed to accounting standards are significantly more likely to be equity or capital asset issues.

2.2.4 Restatements related to the quality of financial audit. According to prior literature, as the audit quality and auditor industry specialization increase, the number of accounting restatements reduces dramatically. For instance, Chin and Chi (2009) reveal that clients of signing auditor specialists, either alone or in conjunction with firm-level specialists, are less likely to make accounting restatements relative to those of other auditors.

\subsection{Research background}

Empirical literature on accounting conservatism has developed extensively over the last two decades, particularly since the seminal work of Basu (1997) as an introduction to the concept of conservatism. Scholars have attempted to quantify conservatism (using DT measure) and its relationship with other accounting scopes. Conservatism definition, its proxies, interested groups and the cross-sectional and time-series variations in accounting conservatism have been the subject of close scrutiny and highly referred research questions in the prior literature. Several different explanations have been suggested for conservative accounting. Watts (2003), for instance, reviews these explanations and argues that contracting conservatism (conservative contracts between the efficient technology employed in the firm and other various parties), shareholder litigation costs, the linkage between taxation and financial reporting and, finally, financial reporting standard setters and regulators are among the most plausible explanations offered for the conservative accounting. What follows is a succinct review of the cross-sectional variations of conservatism categorized into three relationships with corporate governance, investment efficiency and financial restatements.

2.3.1 Corporate governance and accounting conservatism. It is generally argued that conservatism provides the promising ground for aligning the conflicts of interests between the parties to a firm by restricting managers' opportunistic behavior and improving contract efficiency through timelier recognition of covenant violations (Lara et al., 2009). Beeks et al. (2004) indicate that higher proportion of outsiders in the board of directors leads to greater accounting conservatism. Specifically, firms incorporate bad news into earnings in a timelier manner when their board of directors is more independent. Likewise, Ahmed and Duellman (2007) find a positive relationship between accounting conservatism and the percentage of outside directors' shareholding. Lara et al. (2009) provide some evidence on the relationship between corporate governance structure and accounting conservatism supporting earlier studies. They find a positive causality flowing from governance to conservatism (not vice versa), implying that corporate governance and conservatism are not substitutes. Jaggi et al. (2015) find that adopting meeting/beating market expectations negatively affects accounting conservatism and leads corporate managers to sacrifice the benefit associated with accounting conservatism. They argue that the preceding significant relationship is influenced negatively by antitakeover provisions as a corporate governance mechanism. Caskey and Laux (2016) contend that accounting conservatism acts like a double-edge sword, that is, while it allows the corporate board to better oversee the firm's investment decisions, accounting system manipulation is likely to occur by managers to mislead and distort the board decisions. Nasr and Ntim (2018) examine the effect of corporate governance mechanisms on accounting conservatism in Egypt and find a positive relationship between board independence and accounting conservatism. By contrast, their findings suggest a 
negative relationship between other aspects of corporate governance structure (e.g. board size and auditor type) and conservatism. In a similar vein, El-habashy (2019) examines the effect of corporate governance attributes on accounting conservatism for a sample of the 40 most active nonfinancial Egyptian companies. He demonstrates that board independence and audit quality positively affect accounting conservatism, whereas institutional ownership and large block shares have a significant negative association.

2.3.2 Investment efficiency and accounting conservatism. Prior research suggests that manager's incentive to invest in poorly performing and negative NPV projects is likely to be influenced by accounting conservatism. In other words, accounting conservatism compels corporate managers to avoid investing in negative NPV projects and recognize losses in a timelier manner, probably because their compensation is mainly dependent on earnings (Watts, 2003; Ball and Shivakumar, 2005; Francis and Martin, 2010). Consistent with the argument that conservative firms possess profitable acquisitions, Ahmed and Duellman (2011) indicate that higher gross margins, higher cash flows and lower degree of special item charges after acquisitions are more pronounced in conservative firms. The cross-country study of Bushman et al. (2011) suggests that investment responses and sensitivity to declining opportunities increase with the timeliness of accounting recognition of economic losses reflected in sample countries' accounting regime. However, their findings do not support the fact that accounting conservatism affects the investment sensitivity to increasing investment opportunities. Lara et al. (2016) investigate the relation between accounting conservatism and investment efficiency and argue that conservatism improves investment efficiency by mitigating underinvestment through facilitating access to debt financing. Furthermore, this effect is more pronounced in the wake of higher information asymmetry. They also show that conservatism is significantly associated with overinvestment, particularly for opaque investments such as research and development.

After controlling for managerial ability, corporate governance and other investments, Ha and Feng (2018) similarly examine the relation between conditional conservatism (i.e. asymmetric timely recognition of losses vs gains) and labor investment efficiency and find that conservatism reduces inefficient investment practices on the labor market, including overhiring, underfiring, underhiring and overfiring. The authors contend that this happens by means of mitigating information asymmetry between management and investors. Laux (2020) provide some evidence regarding conservative reporting and its impact on managerial incentive to come up with more innovative ideas. Their findings suggest that as long as conservative reporting reduces the risk of overstatement, innovative projects in organization will be developed and flourished significantly.

2.3.3 Financial restatements and conservative reporting. Prior literature suggests that financial restatements generate substantial declines in stock prices, followed by decreases in expected earnings and increased cost of capital (Hribar and Jenkins, 2004) and lawsuits (Palmrose and Scholz, 2004). Based on the results of this line of research, more negative returns are associated with restatements involving fraud, affecting more accounts, decreasing reported income and attributed to auditors or management. Further, an additional penalty is often considered for announcements that do not quantify the restatement (Palmrose et al., 2004).

Several academic works investigated the possible effects of restatements on corporate governance mechanisms as well. In this regard, Srinivasan (2005) and Desai et al. (2006) argue that directors and managers of restating companies encounter an increased likelihood of job loss. More specifically, the violation of GAAP by corporate boards and external labor market is significantly penalized. Investigating the long-run effects of accounting restatements on the market value of a sample of 405 companies announcing restatements of their financial statements from 1995 to 1999, Hirschey et al. (2003) indicate that the overall postannouncement abnormal returns for restating companies are nonsignificantly 
AJAR 5,1

negative, suggesting the ability of current accounting earnings information to predict future abnormal returns in the stock market. In a more recent study, Wilson (2008) conducts an empirical analysis to examine characteristics of the decline in the information content of earnings. His findings particularly show that a temporary loss in information content of earnings is observable following the occurrence of restatements.

Another aspect of present study has been challenged by Huang and Zhang (2009). They examine the level of conservative reporting among restating firms as compared to their counterparts and find that the restating firms report conservatively in comparison to nonrestatement periods. In a similar study, Xu (2009) attempts to recognize the impact of restatement announcement on financial reporting quality as captured by conservatism. As measured by CEO annual compensation, conservatism increases significantly parallel the increased usage of option grants during the prior period of restatements. This alleviates severe agency problems arising from CEO option grants and also reduces aggressive accounting behavior.

Recent papers have also drawn a distinction between conditional and unconditional conservatism. For instance, Lagore and Morton (2009) seek to find whether financial restatements lead to greater conservatism. Their results suggest that restating firms undertake greater conditional conservatism in the three years subsequent to a restatement announcement. Further, in line with their primary conjecture, enhanced contract efficiency has been observed for firms whose reporting is more conservative. In a study conducted by Plumlee and Yohn (2010), the primary drivers of restatements have been investigated. The authors argue that restatements mainly stem from a company's internal function error along with a significant portion attributed to accounting standards. Inconsistent with prior literature claiming the complexity of accounting as the main cause of restatements, this study suggests that the misapplications of generally accepted accounting standards are attributable to the occurrence of accounting restatements.

Chang et al. (2011) provide insight into the relationship between conservative earning strategies and restatements. They investigate a firm's reporting behavior in restoring a damaged reputation subsequent to announcements of restatements. In this regard, they use discretionary accruals to quantify conservatism and show that an increase in financial restatements is accompanied by the adoption of more conservative accounting principles. Using Basu's (1997) differential timeliness metric and the related C-score metric, Ettredge et al. (2012) examine the relationship between earning restatements and differential timeliness of accounting conservatism and indicate that restating firms undertake lower conservatism during overstated earnings periods. In addition, the underlying conservatism in restating companies indicated a significant increase in periods subsequent to overstatements. The authors suggest that the prerequisite for increased level of conservatism is enhanced corporate governance structure of firms. The impact of financial restatements on managers' subsequent earning forecasts has also been examined by Ettredge et al. (2013). They show that the issuance of quarterly earnings forecast is lower for restating firms than for their counterparts. Furthermore, their results are indicative of fewer forecasts in postrestatement periods. The most recent evidence from pre- and post-SOX eras has been introduced by Chen et al. (2014). They seek to examine financial reporting conservatism of firms having reacted negatively to the market. Using Basu's (1997) measure of conservatism, these firms undertake higher conservatism in their financial reporting in the aftermath of the passage of the SOX. Kim et al. (2018) examine CFO's preference for accounting conservatism and the likelihood of financial restatement and indicate that the likelihood of annual report restatement in firms with conservative CFOs is lower.

Bringing together the existing empirical evidence and our theoretical framework, we have the prediction that restating firms as compared to their counterparts undertake lower conservatism during prerestatement period. In contrast, we expect higher conservatism for 
the restating firms during the restatement period. Finally, we envisage capturing higher conservatism for the restating firms during restatement years than prerestatement periods. Based on the preceding expectations, we posit our hypotheses as follows:

H1. Restating firms as compared to their counterparts undertake lower conservatism during prerestatement period.

H2. Restating firms as compared to their counterparts undertake higher conservatism during the restatement period.

H3. Restating firms undertake higher conservatism during restatement years than prerestatement periods.

\section{Empirical methodology}

As discussed previously, the present study employs Basu (1997) and Khan and Watts' (2009) DT metrics as proxies for conservatism. According to Basu (1997), conservatism is measured as the extent to which negative returns (bad news) are reflected in reported earnings in a timelier fashion than positive returns (good news). The Basu model is as follows:

$$
\mathrm{NI}_{i t}=\alpha_{0}+\alpha_{1} \mathrm{NEG}_{i t}+\alpha_{2} \mathrm{RET}_{i t}+\alpha_{3} \mathrm{RET}_{i t} \times \mathrm{NEG}_{i t}+\varepsilon_{i t}
$$

where:

$\mathrm{NI}_{i t}=$ The scaled net income before extraordinary items of firm $i$ for year $t$;

$\mathrm{RET}_{i t}=$ Annual buy-and-hold return of firm $i$ in year $t$, calculated as returns from the fourth months after the fiscal year-end in year $t-1$ to the fourth month after the fiscal yearend date in year $t$;

$\mathrm{NEG}_{i t}=$ Indicator variable equal to 1 if $\mathrm{RET}_{i t}$ is negative, and 0 otherwise;

$\alpha_{2}=$ The slope coefficient for positive RET $i t$;

$\alpha_{3}=$ The differential slope for bad versus good economic news (differential timeliness, DT)

$\alpha_{2}+\alpha_{3}=$ The slope coefficient for negative $\operatorname{RET}_{i t}$.

The following equation will be obtained if the stock return is positive: $\mathrm{NI}=\alpha_{0}+\alpha_{2} \mathrm{RET}_{i t}+\varepsilon$, where $\alpha_{2}$ indicates the sensitivity of earnings to good news. In contrast, the resultant equation of negative stock returns will be: $\mathrm{NI}=\alpha_{0}+\alpha_{1}+$ $\left(\alpha_{2}+\alpha_{3}\right) \times \mathrm{RET}_{i, t}$, where $\alpha_{2}+\alpha_{3}$ represents the sensitivity of earnings to bad news. Basu (1997) argues that earnings respond to bad news in a timelier fashion than good news (i.e. $\alpha_{2}<\alpha_{2}+\alpha_{3}$ or $\alpha_{3}>0$ ). In this regard, $\alpha_{3}$ is the DT coefficient of earnings indicating the conservatism (differential coefficient of bad news as compared to good news). As $\alpha_{3}$ increases, the asymmetric timeliness in recognizing bad or good news rises and consequently affects the level of accounting conservatism.

Using cross-sectional approach, we examine the effectiveness of DT and C-score measures of conservatism following the occurrence of earnings restatements for two different samples, namely restating firms and their counterparts (nonrestating forms). The present paper matched two groups based on their similar characteristics during the prerestatement period. Afterward, we compare the conservatism metrics of test companies and control companies (1) during the years prior to onset of restatements and (2) during the years of restatement announcements. To capture differences in conservatism between the test and control companies, we extend model (1) by including the variable TESTFIRM $M_{i t}$, coded as 1 for a test company $i$ in period $t$ and as 0 for company $i$ 's matching control firm(s) in period $t$. The expanded model is as follows:

\section{Capturing differences in conservatism}


AJAR

5,1

$$
\begin{aligned}
\mathrm{NI}_{i t}= & \alpha_{0}+\alpha_{1} \mathrm{NEG}_{i t}+\alpha_{2} \mathrm{RET}_{i t}+\alpha_{3} \mathrm{RET}_{i t} \times \mathrm{NEG}_{i t}+\alpha_{4} \mathrm{Test} \mathrm{Firm}_{i t} \\
& +\alpha_{5} \mathrm{Test}_{\text {Firm }} \times \mathrm{NEG}_{i t}+\alpha_{6} \mathrm{Test} \mathrm{Firm}_{i t} \times \mathrm{RET}_{i t} \\
& +\alpha_{7} \mathrm{Test} \mathrm{Firm}_{i} \times \mathrm{RET}_{i t} \times \mathrm{NEG}_{i t}+\alpha_{8} \mathrm{MTB}_{i t-1}+\alpha_{9} \mathrm{MTB}_{i t-1} \times \mathrm{NEG}_{i t} \\
& +\alpha_{10} \mathrm{MTB}_{i t-1} \times \mathrm{RET}_{i t}+\alpha_{11} \mathrm{MTB}_{i t-1} \times \mathrm{RET}_{i t} \times \mathrm{NEG}_{i t}+\alpha_{12} \mathrm{LEV}_{i t-1} \\
& +\alpha_{13} \mathrm{LEV}_{i t-1} \times \mathrm{NEG}_{i t}+\alpha_{14} \mathrm{LEV}_{i t-1} \times \mathrm{RET}_{i t}+\alpha_{15} \mathrm{LEV}_{i t-1} \times \mathrm{RET}_{i t} \times \mathrm{NEG}_{i t} \\
& +\alpha_{16} \mathrm{size}_{i t-1}+\alpha_{17} \mathrm{siza}_{i t-1} \times \mathrm{NEG}_{i t}+\alpha_{18} \mathrm{size}_{i t-1} \times \mathrm{RET}_{i t} \\
& +\alpha_{19} \mathrm{size}_{i t-1} \times \mathrm{RET}_{i t} \times \mathrm{NEG}_{i t}+\alpha_{20} \mathrm{LIT}_{i t-1}+\alpha_{21} \mathrm{LIT}_{i t-1} \times \mathrm{NEG}_{i t} \\
& +\alpha_{22} \mathrm{LIT}_{i t-1} \times \mathrm{RET}_{i t}+\alpha_{23} \mathrm{LIT}_{i t-1} \times \mathrm{RET}_{i t} \times \mathrm{NEG}_{i t}+\varepsilon_{i t}
\end{aligned}
$$

We include a number of control variables to ensure that conservatism is not influenced by other operating characteristics of restating firms and do not differ from the control firms. The full set of controls includes firm size (as a proxy for political costs, aggregation of income and returns across multiple segments and projects and information asymmetry), leverage, market-to-book ratio and executive compensation (LaFond and Roychowdhury, 2008; LaFond and Watts, 2008; Ettredge et al., 2012). Estimating Eqn (2) in the periods prior to the onset of earnings restatement, $\alpha_{3}$ quantifies the conservatism of nonrestating firms and $\alpha_{7}$ is indicative of the differential conservatism of restating companies. If Basu's DT metric captures a lower conservatism for test firms as compared to nonrestating firms during prerestatement years, then we expect $\alpha_{7}$ to be negative (i.e. $\alpha_{3}+\alpha_{7}>\alpha_{3}$ ). Next, we estimate aforementioned model using observations from periods during which earnings restatements occurred. In this case, $\alpha_{7}$ is expected to be positive if the test firms exhibit greater conservatism as compared to their peer control firms.

Time-series approach compares the restating companies' earnings conservatism in the years when earnings were restated and years prior to the occurrence of earnings restatements. Under this approach, each test company controls its own characteristics. To capture differences in conservatism between the test and control companies, this paper

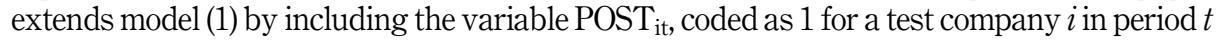
and as 0 for company $i$ 's matching control firm(s) in period $t$. The expanded model is represented as follows:

$$
\begin{aligned}
\mathrm{NI}_{i t}= & \alpha_{0}+\alpha_{1} \mathrm{NEG}_{i t}+\alpha_{2} \mathrm{RET}_{i t}+\alpha_{3} \mathrm{RET}_{i t} \times \mathrm{NEG}_{i t}+\alpha_{4} \mathrm{post}_{i t}+\alpha_{5} \mathrm{post}_{i t} \times \mathrm{NEG}_{i t} \\
& +\alpha_{6} \mathrm{post}_{i t} \times \mathrm{RET}_{i t}+\alpha_{7} \mathrm{post}_{i t} \times \mathrm{RET}_{i t} \times \mathrm{NEG}_{i t}+\alpha_{8} \mathrm{MTB}_{i t-1} \\
& +\alpha_{9} \mathrm{MTB}_{i t-1} \times \mathrm{NEG}_{i t}+\alpha_{10} \mathrm{MTB}_{i t-1} \times \mathrm{RET}_{i t}+\alpha_{11} \mathrm{MTB}_{i t-1} \times \mathrm{RET}_{i t} \times \mathrm{NEG}_{i t} \\
& +\alpha_{12} \mathrm{LEV}_{i t-1}+\alpha_{13} \mathrm{LEV}_{i t-1} \times \mathrm{NEG}_{i t}+\alpha_{14} \mathrm{LEV}_{i t-1} \times \mathrm{RET}_{i t} \\
& +\alpha_{15} \mathrm{LEV}_{i t-1} \times \mathrm{RET}_{i t} \times \mathrm{NEG}_{i t}+\alpha_{16} \mathrm{size}_{i t-1}+\alpha_{17} \operatorname{size}_{i t-1} \times \mathrm{NEG}_{i t} \\
& +\alpha_{18} \mathrm{size}_{i t-1} \times \mathrm{RET}_{i t}+\alpha_{19} \mathrm{size}_{i t-1} \times \mathrm{RET}_{i t} \times \mathrm{NEG}_{i t}+\alpha_{20} \mathrm{LIT}_{i t-1} \\
& +\alpha_{21} \mathrm{LIT}_{i t-1} \times \mathrm{NEG}_{i t}+\alpha_{22} \mathrm{LIT}_{i t-1} \times \mathrm{RET}_{i t}+\alpha_{23} \mathrm{LIT}_{i t-1} \times \mathrm{RET}_{i t} \times \mathrm{NEG}_{i t}+\varepsilon_{i t}
\end{aligned}
$$

In Eqn (3), $\alpha_{3}$ measures the conservatism of periods prior to the occurrence of earnings restatements. It is expected that coefficient $\alpha_{7}$ to be nonnegative (or positive) as an indication of greater conservatism during the restatements years.

\subsection{Sample selection process}

We obtain our required data manually from the hardcopy financial statements held in the TSE library (i.e. Codal [2] and its supplementary software known as Rahavard Novin) for 
the sample period 2009-2013. To construct our sample for the paper's hypotheses, the sample process begins with all client-year observations on the Codal database (the number of all listed companies yielded a potential statistical population of 507 firms). Then firms with noncalendar fiscal year end [3] (6 firms), firms with missing or insufficient variable data (12 firms) and firms with fiscal year change during 2009-2013 (6 firms) are excluded from our sample. Further, firms operating in banking industry as well as financial and investment institutions (10 firms) are excluded to calculate the variables used in our equation, primarily because financial institutions and banking industry have different reporting requirements that could influence the figures associated with dependent variables.

To clearly distinguish prerestatement periods from periods during which earnings restatements occur, we restrict the test sample to companies that disclose at least a single restatement during March 20, 2009, through March 20, 2013, although the restatement can correct errors in more than one prior year. Multiple disclosures concerning one restatement event are treated as one restatement. As such, firms not meeting the previously mentioned criterion are entirely excluded (301 firms). It is also required that test companies have at least one year of data available both before and during the restatement years. This leaves a primary sample of 172 firms (860 firm-year observations). It is also noteworthy that the research sample represents $38-46 \%$ cases for each year and does not indicate any bias regarding missing data except for a greater proportion of missing cases for the beginning and closing year of the series. Table 1

Panel A: Sample selection procedure

Initial population of industrial firms with required data for estimating variables derived from the 507 TSE database for the sample period 2009-2013

Less $\quad$ Firms with noncalendar fiscal year end $\quad 6$

Less $\quad$ Firms with missing or insufficient variable data $\quad 12$

Less $\quad$ Firms with fiscal year change during 2009-2013 6

Less $\quad$ Firms operating in banking industry as well as financial and investment institutions $\quad 10$

$\begin{array}{ll}\text { Less } \quad \text { Nonrestating firms } & 301\end{array}$

$\begin{array}{ll}\text { Equal Total firms in sample } & 172\end{array}$

Panel B: No. of firms by Industry

\begin{tabular}{lcc} 
Industry & Frequency & Percentage \\
\hline Telecommunications & 13 & 7.55 \\
Construction & 13 & 7.55 \\
Automotive & 13 & 7.55 \\
Electronics and Computer & 10 & 5.81 \\
Mining and Metal Products & 13 & 7.55 \\
Non-Metallic Minerals & 12 & 6.97 \\
Cement and Plaster & 15 & 8.72 \\
Metals & 14 & 8.13 \\
Agriculture and Animal Husbandry & 11 & 6.39 \\
Rubber and Plastic & 11 & 6.39 \\
Machine Tools & 13 & 7.55 \\
Oil, Gas and Petrochemicals & 13 & 7.55 \\
Food & 13 & 7.55 \\
Pharmaceuticals and Healthcare & 13 & 7.55 \\
Total & 172 & 100
\end{tabular}

Table 1.

Sample selection process 
AJAR

5,1

discusses the breakdown of sample procedure (Panel A) as well as the number of firms per industry (Panel B).

\section{Results and discussion}

\subsection{Descriptive statistics for restating firms (test firms)}

Table 2 exhibits the descriptive statistics for the research variables classified under three periods $(t, t-1, t-2)$. The results shown in the following table indicate that there have been some missing observations for the majority of variables. Based on Basu's expanded model, the restatement date can lag behind the end of restatements (i.e. one or two years prior to restatements). Accordingly, we measured the required data for a total number of 172 firms during three periods $(t, t-1, t-2)$.

\subsection{Descriptive statistics for nonrestating firms (control firms)}

As it is evident in Table 3, a total number of 301 nonrestating firms during two periods were investigated. The results indicate that RET or stock returns (in percentage terms) show the

\begin{tabular}{rlrrrrrr}
\hline Period & Symbol & $N$ & Min & Max & Std. Deviation & Mean & Range \\
\hline \multirow{2}{*}{$t-2$} & LEV & 172 & 0.01 & 7.51 & 0.75 & 0.70 & 7.15 \\
& LIT & 50 & 0.00 & 6.62 & 0.93 & 0.15 & 6.62 \\
& MTB & 144 & -43.79 & 12.23 & 4.50 & 1.14 & 56.02 \\
& NI & 172 & -0.85 & 88.88 & 6.87 & 0.67 & 89.72 \\
& RET & 172 & -56.52 & 535.33 & 61.49 & 26.88 & 591.85 \\
& SIZE & 172 & 10.152 & 13.96 & 2.76 & 11.15 & 3.81 \\
$t-1$ & LEV & 172 & 0.01 & 7.51 & 0.96 & 0.84 & 7.51 \\
& LIT & 56 & 0.00 & 0.06 & 0.01 & 0.01 & 0.06 \\
& MTB & 172 & -22.88 & 56.82 & 5.19 & 1.44 & 79.70 \\
& NI & 172 & -0.70 & 93.79 & 10.27 & 1.32 & 94.48 \\
& RET & 119 & $-72 / 38$ & 535.33 & 92.11 & 28.22 & 607.71 \\
& SIZE & 172 & 10.17 & 14.01 & 1.94 & 11.56 & 3.83 \\
& LEV & 171 & 0.04 & 7.51 & 1.04 & 0.90 & 7.48 \\
& LIT & 54 & 0.00 & 0.05 & 0.01 & 0.01 & 0.05 \\
& MTB & 171 & -25.92 & 56.82 & 7.03 & 1.71 & 82.73 \\
& NI & 171 & -77.66 & 93.79 & 11.53 & 0.63 & 170.94 \\
& RET & 124 & -76.38 & 452.12 & 91.48 & 37.14 & 528.50 \\
& SIZE & 171 & 10.18 & 14.01 & 0.92 & 11.87 & 3.83 \\
\hline
\end{tabular}

Table 2.

Descriptive statistics for restating firms (test firms)

\begin{tabular}{|c|c|c|c|c|c|c|c|}
\hline Period & Symbol & $N$ & Min & $\operatorname{Max}$ & Mean & Std. Deviation & Range \\
\hline \multirow[t]{6}{*}{$t-1$} & LEV & 301 & 0.03 & 2.36 & 0.66 & 0.29 & 2.32 \\
\hline & LIT & 98 & 0.00 & 0.30 & 0.02 & 0.04 & 0.30 \\
\hline & MTB & 284 & -56.54 & 25.65 & 1.60 & 4.37 & 82.19 \\
\hline & NI & 301 & -0.72 & 0.51 & 0.10 & 0.14 & 1.23 \\
\hline & RET & 273 & -79.52 & 833.95 & 23.24 & 73.51 & 913.47 \\
\hline & SIZE & 301 & 10.38 & 13.96 & 11.80 & 0.66 & 3.58 \\
\hline \multirow[t]{6}{*}{$T$} & LEV & 301 & 0.01 & 3.29 & 0.68 & 0.39 & 3.28 \\
\hline & LIT & 130 & 0.00 & 6.62 & 0.07 & 0.058 & 6.62 \\
\hline & MTB & 286 & -21.29 & 56.82 & 2.02 & 4.13 & 78.11 \\
\hline & NI & 301 & -0.61 & 0.63 & 0.09 & 0.16 & 1.24 \\
\hline & RET & 276 & -58.23 & 734.14 & 41.79 & 101.82 & 792.37 \\
\hline & SIZE & 301 & 10.38 & 14.04 & 11.85 & 0.67 & 3.66 \\
\hline
\end{tabular}

Table 3

Descriptive statistics for nonrestating firms (control firms) 
highest dispersion (range) among other values. Furthermore, it represents the highest value on the average as well (mean).

\subsection{Test of normality}

We used Kolmogorov-Smirnov test to ensure whether model coefficients are significantly different from zero (normality of error distribution). The results of this test are shown in Table 4. Since the probability values of both models are more than the significance level of 0.05 , the normal distribution of errors is confirmed at the $95 \%$ confidence interval, that is, none of them was violated.

\subsection{Estimation results for first hypothesis}

We use the following expanded regression model to test our first hypothesis [4]:

$$
\begin{aligned}
\mathrm{NI}_{i t}= & \alpha_{0}+\alpha_{1} \mathrm{NEG}_{i t}+\alpha_{2} \mathrm{RET}_{i t}+\alpha_{3} \mathrm{RET}_{i t} \times \mathrm{NEG}_{i t}+\alpha_{4} \mathrm{Test} \mathrm{Firm}_{i t} \\
& +\alpha_{5} \mathrm{TestFirm}_{i t} \times \mathrm{NEG}_{i t}+\alpha_{6} \mathrm{Test} \mathrm{Firm}_{i t} \times \mathrm{RET}_{i t} \\
& +\alpha_{7} \mathrm{TestFirm}_{i t} \times \mathrm{RET}_{i t} \times \mathrm{NEG}_{i t}+\alpha_{8} \mathrm{MTB}_{i t-1}+\alpha_{9} \mathrm{MTB}_{i t-1} \times \mathrm{NEG}_{i t} \\
& +\alpha_{10} \mathrm{MTB}_{i t-1} * \mathrm{RET}_{i t}+\alpha_{11} \mathrm{MTB}_{i t-1} \times \mathrm{RET}_{i t} \times \mathrm{NEG}_{i t}+\alpha_{12} \mathrm{LEV}_{i t-1} \\
& +\alpha_{13} \mathrm{LEV}_{i t-1} \times \mathrm{NEG}_{i t}+\alpha_{14} \mathrm{LEV}_{i t-1} \times \mathrm{RET}_{i t}+\alpha_{15} \mathrm{LEV}_{i t-1} \times \mathrm{RET}_{i t} \times \mathrm{NEG}_{i t} \\
& +\alpha_{16} \mathrm{size}_{i t-1}+\alpha_{17} \operatorname{siza}_{i t-1} \times \mathrm{NEG}_{i t}+\alpha_{18} \operatorname{size}_{i t-1} \times \mathrm{RET}_{i t} \\
& +\alpha_{19} \operatorname{size}_{i t-1} \times \mathrm{RET}_{i t} \times \mathrm{NEG}_{i t}+\alpha_{20} \mathrm{LIT}_{i t-1}+\alpha_{21} \mathrm{LIT}_{i t-1} \times \mathrm{NEG}_{i t} \\
& +\alpha_{22} \mathrm{LIT}_{i t-1} \times \mathrm{RET}_{i t}+\alpha_{23} \mathrm{LIT}_{i t-1} \times \mathrm{RET}_{i t} \times \mathrm{NEG}_{i t}+\varepsilon_{i t}
\end{aligned}
$$

From statistics viewpoint, the presence of outliers in the model makes the error distribution to be skewed. Accordingly, we employ box plots to identify and eliminate the adverse effects of outliers in the regression model. Using box plots in a six-step process, the outliers were eliminated and led to box plot on the left side of Figure 1.

Although the distance between the third quartile and the median is more than the distance between the first quartile and median, the effect of outliers is eliminated entirely. Eliminating firms with net income outliers allows us to fit regression model (4) to the observations. The results are shown in Table 5 .

The results shown in Table 5 indicate that coefficient $\alpha_{3}$ in Basu's expanded regression model is positive. These findings are in line with those of Basu's (1997). In other words, it is argued that earnings respond to bad news in a timelier fashion than good news (i.e. $\alpha_{2}<\alpha_{2}+\alpha_{3}$ or $\alpha_{3}>0$ ). Moreover, if Basu's DT metric captures a higher conservatism for restating firms than for nonrestating firms during prerestatement years, then $\alpha_{7}$ should be positive (i.e. $\alpha_{3}+\alpha_{7}>\alpha_{3}$ ). As it is evident in the given table, regression coefficient for TESTFIRM $t_{-} 1 \times R E T \_t \_1 \times N E G_{-} t \_1$, as a measure of restating firms' conservatism in comparison to nonrestating firms in the years prior to restatements, demonstrates a value of 0.252 and a probability value of 0.000 . Accordingly, the first

\begin{tabular}{lccccc}
\hline Model & $N$ & Mean & Std. deviation & $Z$ statistic & Sig. \\
\hline Basu's expanded model (H1) & 362 & 0.000 & 1.972 & 1.023 & 0.306 \\
Khan-Watts' expanded model (H1) & 362 & 0.000 & 4.0253 & 0.998 & 0.318 \\
Basu's expanded model (H2) & 361 & 0.000 & 0.1343 & 1.137 & 0.2555 \\
Khan-Watts' expanded model (H2) & 361 & 0.000 & 0.1201 & 1.226 & 0.2201 \\
Basu's expanded model (H3) & 338 & 0.000 & 0.1343 & 1.102 & 0.270 \\
Khan-Watts' expanded model (H3) & 338 & 0.000 & 0.1294 & 1.521 & 0.128
\end{tabular}

Capturing differences in conservatism

$+$ 
AJAR
5,1

160

Figure 1.

Net income box plots in Basu's expanded regression model (first hypothesis)

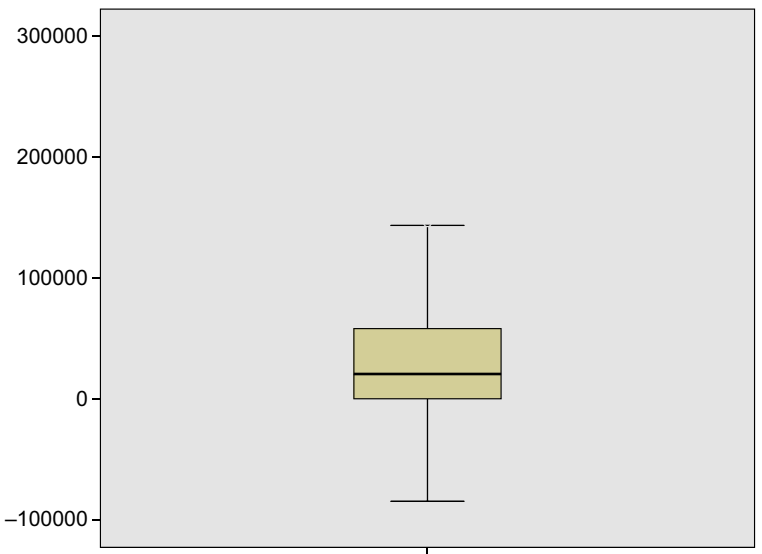

$\mathrm{NI}$ after remove outliers

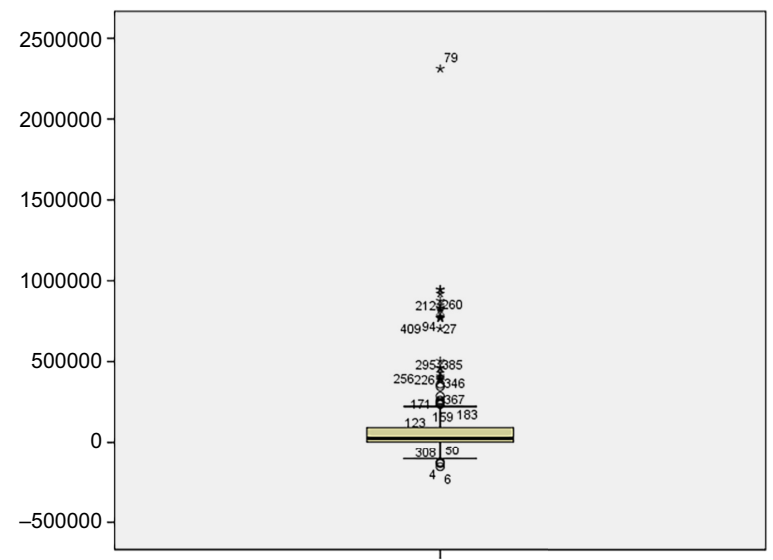

NI before remove outliers

hypothesis is approved at the significance level of $0.05(0.000<0.05)$. In other words, restating firms as compared to their counterparts undertake lower conservatism during prerestatement period. Next, we examine the hypothesis using Khan-Watts' regression model. In this case, the first hypothesis will be confirmed if $\alpha_{7}$ is positive. Table 6 exhibits the results of final fitted model.

$$
\begin{aligned}
\mathrm{NI}_{i t}= & \alpha_{0}+\alpha_{1} \mathrm{NEG}_{i t}+\mu_{0} \mathrm{RET}_{i t}+\mu_{1} \operatorname{size}_{i t} \times \mathrm{RET}_{i t}+\mu_{2} \frac{M}{B_{i t}} \times \mathrm{RET}_{i t}+\mu_{3} \mathrm{LEV}_{i t} \times \mathrm{RET}_{i t} \\
& +\mu_{4} \mathrm{Lit}_{i t} \times \mathrm{RET}_{i t}+\lambda_{0} \mathrm{NEG}_{i t} \times \mathrm{RET}_{i t}+\lambda_{1} \mathrm{size}_{i t} \times \mathrm{NEG}_{i t} \times \mathrm{RET}_{i t} \\
& +\lambda_{2} \frac{M}{B_{i t}} \times \mathrm{NEG}_{i t} \times \mathrm{RET}_{i t}+\lambda_{3} \mathrm{LEV}_{i t} \times \mathrm{NEG}_{i t} \times \mathrm{RET}_{i t}+\lambda_{4} \mathrm{Lit}_{i t} \times \mathrm{NEG}_{i t} \times \mathrm{RET}_{i t} \\
& +\delta_{1} \operatorname{size}_{i t}+\delta_{2} \frac{M}{B_{i t}}+\delta_{3} \mathrm{LEV}_{i t}+\delta_{4} \mathrm{Lit}_{i t}+\delta_{5} \mathrm{NEG}_{i t} \times \operatorname{size}_{i t}+\delta_{6} \mathrm{NEG}_{i t} \times \frac{M}{B_{i t}} \\
& +\delta_{7} \mathrm{NEG}_{i t} \times \mathrm{LEV}_{i t}+\delta_{8} \mathrm{NEG}_{i t} \times \mathrm{Lit}_{i t}+\alpha_{4} \mathrm{Test} \mathrm{Firm}_{i t}+\alpha_{5} \mathrm{Test} \mathrm{Firm}_{i t} \times \mathrm{NEG}_{i t} \\
& +\alpha_{6} \mathrm{TestFirm}_{i t} \times \mathrm{RET}_{i t}+\alpha_{7} \mathrm{Test}_{\text {Firm }} \times \mathrm{RET}_{i t} \times \mathrm{NEG}_{i t}+\varepsilon_{i t}
\end{aligned}
$$




\begin{tabular}{|c|c|c|c|c|c|c|}
\hline Matched on & $\begin{array}{l}\text { Unstan } \\
\text { regre } \\
\text { coeff } \\
B\end{array}$ & $\begin{array}{l}\text { The es } \\
\text { ardized } \\
\text { ssion } \\
\text { ients } \\
\text { Std. } \\
\text { error }\end{array}$ & $\begin{array}{l}\text { Standardized } \\
\text { coefficient } \\
\text { Beta }\end{array}$ & $t$-statistic & Sig & $\begin{array}{l}\text { differences in } \\
\text { conservatism }\end{array}$ \\
\hline (Constant) & 0.059 & 9.480 & - & 0.006 & 0.995 & 161 \\
\hline NEG_t_1 & 83.310 & 18.799 & 6.933 & 4.432 & 0.000 & \\
\hline RET_t_1 & 0.002 & 0.093 & 0.026 & 0.021 & 0.983 & \\
\hline RET_t$t \_1 \times$ NEG_t_1 & 2.500 & 0.596 & 6.264 & 4.197 & 0.000 & \\
\hline TESTFIRM_t_1 & 0.000 & 1.130 & 0.000 & 0.000 & 1.000 & \\
\hline TESTFIRM $t+1 \times$ NEG_t_1 & 9.729 & 2.110 & 0.532 & 4.610 & 0.000 & \\
\hline TESTFIRM_ $t \_1 \times$ RET $\_t \_1$ & -0.001 & 0.013 & -0.005 & -0.045 & 0.964 & \\
\hline TESTFIRM_t_1 $1 \times$ RET $\_t \_1 \times$ NEG $\_t \_1$ & 0.252 & 0.067 & 0.369 & 3.731 & 0.000 & \\
\hline MTB_t_2 & 0.025 & 0.237 & 0.015 & 0.105 & 0.917 & \\
\hline MTB_t_2$\times$ NEG_t_1 & 0.491 & 0.527 & 0.110 & 0.932 & 0.352 & \\
\hline MTB $\_t \_2 \times$ RET $t \_1$ & 0.000 & 0.001 & -0.014 & -0.096 & 0.924 & \\
\hline MTB $\_t \_2 \times$ RET $t \_1 \times$ NEG $t \_1$ & 0.017 & 0.015 & 0.114 & 1.114 & 0.266 & \\
\hline LEV_t_2 & -0.326 & 1.981 & -0.015 & -0.164 & 0.869 & \\
\hline LEV $t+2 \times N E G \_t \_1$ & -8.373 & 4.024 & -0.510 & -2.081 & 0.038 & \\
\hline $\mathrm{LEV}_{-} t \_2 \times \mathrm{RET}_{-} t \_1$ & 0.001 & 0.037 & 0.008 & 0.023 & 0.981 & \\
\hline $\mathrm{LEV}_{-} t \_2 \times \mathrm{NEG}_{-} t \_1 \times \mathrm{RET}_{-} t \_1$ & -0.244 & 0.163 & -0.463 & -1.496 & 0.136 & \\
\hline SIZE_t_2 & 0.018 & 0.757 & 0.002 & 0.024 & 0.981 & \\
\hline SIZE_t_2 $\times$ NEG_t_1 & -6.685 & 1.603 & -6.645 & -4.171 & 0.000 & \\
\hline $\mathrm{SIZE}_{-} t-2 \times \mathrm{RET}_{-} t \_1$ & 0.000 & 0.007 & -0.025 & -0.023 & 0.982 & \\
\hline $\mathrm{SIZE}_{-} t \_2 \times \mathrm{NEG}_{-} t \_1 \times \mathrm{RET}_{-} t \_1$ & -0.201 & 0.052 & -5.992 & -3.853 & 0.000 & \\
\hline $\mathrm{LIT}_{-} t \_2$ & 0.171 & 18.455 & 0.011 & 0.009 & 0.993 & \\
\hline $\mathrm{LIT}_{-} t+2 \times \mathrm{NEG}_{-} t \_1$ & -27.39 & 52.031 & -0.097 & -0.526 & 0.599 & \\
\hline $\mathrm{LIT}_{-} t \_2 \times \mathrm{RET}_{-} t \_1$ & -0.007 & 0.0702 & -0.012 & -0.010 & 0.992 & \\
\hline $\mathrm{LIT}_{-} t \_2 \times \mathrm{NEG}_{-} t \_1 \times \mathrm{RET}_{-} t \_1$ & -0.826 & 1.756 & -0.087 & -0.470 & 0.638 & \\
\hline Summary of regression model & \multirow{2}{*}{\multicolumn{2}{|c|}{0.440}} & & & \\
\hline Correlation coefficient & & & & & 2.901 & Table 5. \\
\hline$R^{2}$ & \multicolumn{2}{|c|}{0.194} & \multicolumn{2}{|l|}{$p$-value } & 0.00 & Basu's expanded \\
\hline Regression coefficient & \multicolumn{2}{|c|}{0.252} & \multicolumn{2}{|l|}{$t$-statistic } & 3.731 & regression panel model \\
\hline Durbin-Watson statistic & \multicolumn{2}{|c|}{2.151} & \multicolumn{2}{|l|}{$p$-value } & 0.00 & (first hypothesis) \\
\hline
\end{tabular}

According to Table 6, regression coefficient for TESTFIRM_t_1 $\times R E T \_t \_1 \times N E G \_t \_1$, as a measure of restating firms' conservatism in comparison to nonrestating firms in the years prior to restatements, demonstrates a value of 0.270 and a probability value of 0.00 . Therefore, our first hypothesis is approved at the margin of error of 0.05 by using KhanWatts' expanded regression panel model $(0.000<0.05)$. More specifically, restating firms as compared to nonrestating firms undertake lower conservatism during prerestatement period.

An extreme serial correlation in the errors of regression model is often indicative of a misspecified model. This serial correlation (also known as autocorrelation) is created as a result of violation of linearity assumption. As shown in Tables 5 and 6, Durbin-Watson statistics are 2.151 and 2.114, respectively. This indicates that the residuals are not serially correlated. In addition to this, violations of homoskedasticity results in wide confidence intervals. As such, the scatter plots shown in Figure 2 indicate the homoskedasticity of the errors, because they do not follow any particular pattern.

\subsection{Estimation results for second hypothesis}

This paper estimates expanded regression model (4) during restatement periods to test the second hypothesis. In this regard, we employed box plots again to identify and eliminate the 


\begin{tabular}{|c|c|c|c|c|c|c|}
\hline \multirow{4}{*}{$\begin{array}{l}\text { AJAR } \\
5,1\end{array}$} & & & & & & \\
\hline & \multirow[b]{3}{*}{ Matched on } & & \multicolumn{3}{|c|}{ The estimated regression coefficients } & \\
\hline & & \multicolumn{2}{|c|}{$\begin{array}{l}\text { Unstandardized } \\
\text { regression } \\
\text { coefficients } \\
\text { Std. }\end{array}$} & $\begin{array}{c}\text { Standardized } \\
\text { coefficient }\end{array}$ & \multirow[b]{2}{*}{$t$-Statistic } & \multirow[b]{2}{*}{ Sig } \\
\hline & & & $\begin{array}{l}\text { Std. } \\
\text { Error }\end{array}$ & Beta & & \\
\hline \multirow[t]{23}{*}{162} & (Constant) & 0.003 & 11.026 & - & 0.000 & 1.000 \\
\hline & NEG_t_1 & 116.467 & 20.487 & 7.527 & 5.685 & 0.000 \\
\hline & $\begin{array}{l}\mathrm{RET}_{-} t+1 \\
\mathrm{SIZE}_{t}+1 \times \mathrm{RET} t+1\end{array}$ & $\begin{aligned} 0.000 \\
5^{-4.160}\end{aligned}$ & $\begin{array}{l}0.106 \\
0.008\end{array}$ & $\begin{array}{r}0.003 \\
-0.005\end{array}$ & $\begin{array}{r}0.003 \\
-0.005\end{array}$ & $\begin{array}{l}0.998 \\
0.996\end{array}$ \\
\hline & $\operatorname{MTB} t \frac{1}{1} \times \operatorname{RET} t \frac{1}{1}$ & $5^{-5.502}$ & 0.002 & -0.003 & -0.023 & 0.982 \\
\hline & LEV $\_t \_1 \times$ RET $\_t \_1$ & 0.001 & 0.037 & 0.004 & 0.014 & 0.989 \\
\hline & LIT $\_t=1 \times$ RET $\_t-1$ & 0.001 & 0.466 & 0.000 & 0.002 & 0.998 \\
\hline & NEG $t t \_1 \times$ RET $t-1$ & 2.988 & 0.668 & 6.014 & 4.471 & 0.000 \\
\hline & $\mathrm{SIZE}_{-} \bar{t}-1 \times \mathrm{NEG}_{-}^{-} t \_1 \times \mathrm{RET}_{-} t t_{-} 1$ & -0.237 & 0.057 & -5.643 & -4.137 & 0.000 \\
\hline & $\mathrm{MTB}_{-} t t_{1} 1 \times \mathrm{NEG}_{t} t \_1 \times \mathrm{RET}_{-} \mathrm{t} \_1$ & -0.007 & 0.014 & -0.059 & -0.516 & 0.606 \\
\hline & LEV $t t-1 \times$ NEG_t$t 1 \times$ RET_t $t=1$ & -0.300 & 0.150 & -0.501 & -1.998 & 0.047 \\
\hline & 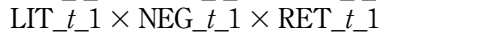 & -2.427 & 2.398 & -0.189 & -1.012 & 0.312 \\
\hline & SIZE_t_t 1 & 0.024 & 0.883 & 0.002 & 0.028 & 0.978 \\
\hline & MTB $\_t \_1$ & 0.023 & 0.308 & 0.008 & 0.075 & 0.940 \\
\hline & LEV_t_t 1 & -0.329 & 2.118 & -0.014 & -0.156 & 0.876 \\
\hline & LIT_t $t_{1} 1$ & -0.214 & 37.735 & -0.0001 & -0.006 & 0.995 \\
\hline & $\mathrm{NEG}-\bar{t} t 1 \times \mathrm{SIZE} \_t \_1$ & -8.923 & 1.731 & -6.863 & -5.154 & 0.000 \\
\hline & NEG $\_t \_1 \times$ MTB $\_t \_1$ & -0.101 & 0.495 & -0.028 & -0.205 & 0.838 \\
\hline & $\mathrm{NEG}_{-} t-1 \times \mathrm{LEV} \_t-1$ & -17.041 & 4.256 & -0.878 & -4.005 & 0.000 \\
\hline & NEG_t $t=1 \times$ LIT_t $t 1$ & -78.068 & 83.330 & -0.193 & -0.937 & 0.350 \\
\hline & TESTFIRM_t_1 & -0.021 & 1.339 & -0.001 & -0.016 & 0.987 \\
\hline & TESTFIRM $\_t-1 \times N E G \_t \_1$ & 12.881 & 2.448 & 0.589 & 5.262 & 0.000 \\
\hline & TESTFIRM_ $t-1 \times$ RET_t_1 & 0.000 & 0.015 & -0.001 & -0.012 & 0.990 \\
\hline & TESTFIRM_t_1 $1 \times$ RET_t_ $1 \times$ NEG_t_1 & 0.270 & 0.074 & 0.363 & 3.662 & 0.000 \\
\hline Table 6. & \multicolumn{6}{|l|}{ Summary of regression models } \\
\hline Khan-Watts' & Correlation coefficient & \multicolumn{2}{|c|}{0.532} & $F$-statistic & \multicolumn{2}{|c|}{5.003} \\
\hline expanded regression & & \multicolumn{2}{|c|}{0.283} & $p$-value & \multicolumn{2}{|c|}{0.00} \\
\hline panel model (first & Regression coefficient & \multirow{2}{*}{\multicolumn{2}{|c|}{$\begin{array}{l}0.270 \\
2.114\end{array}$}} & $t$-statistic & \multirow{2}{*}{\multicolumn{2}{|c|}{$\begin{array}{l}3.662 \\
0.00\end{array}$}} \\
\hline hypothesis) & Durbin-Watson statistic & & & $p$-value & & \\
\hline
\end{tabular}

adverse effects of outliers in the regression model. The box plot on the right side of Figure 3 demonstrates the net income after eliminating outliers. The box plot implies that the tail on the right side of the income distribution is longer or fatter than the left side.

According to Table 7 , regression coefficient for TESTFIRM $t \_1 \times$ RET $\_t \_1 \times$ NEG $\_t \_1$, as a measure of restating firms' conservatism in comparison to nonrestating firms during restatement periods, shows a value of 0.452 and a probability value of 0.012 . Therefore, our second hypothesis is approved at the margin of error of 0.05 by using Basu's expanded regression panel model $(0.012<0.05)$. More specifically, restating firms as compared to their counterparts undertake higher conservatism during the restatement period.

Next, we examine the same hypothesis using Khan-Watts' regression model (5). Table 8 shows the results of final fitted model. According to this table, regression coefficient for $T E S T F I R M \_t \times R E T \_t \times N E G \_t$ demonstrates a value of 0.151 and a probability value of 0.043 . Therefore, our second hypothesis is approved at the margin of error of 0.05 by using Khan-Watts' expanded regression panel model $(0.000<0.05)$. In other words, restating firms undertake higher conservatism during the restatement period. 

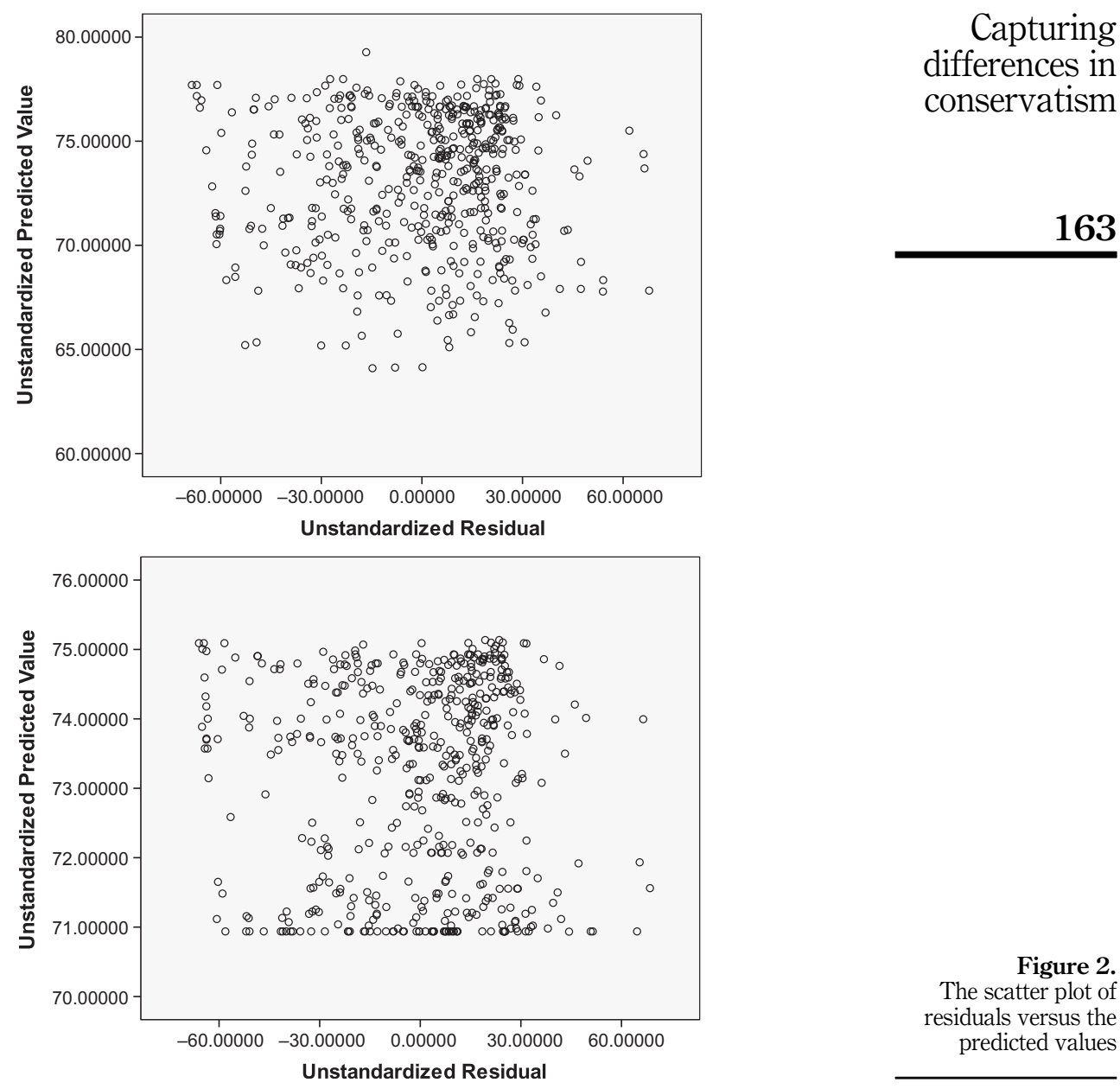

Figure 2.

The scatter plot of residuals versus the predicted values

The results of both conservatism metrics for the second hypothesis indicate that restating firms undertake higher conservatism than nonrestating firms during the restatement periods and at $95 \%$ of confidence interval. Furthermore, the cross-sectional approach provides us with empirical evidence that there is a significant relationship between conservatism and the occurrence of earnings restatements simply during the restatements periods. Using timeseries approach and including the variable post $t_{i t}$ in models, we test our third hypothesis in the reminder of this paper.

4.6 Estimation results for third hypothesis

To test this hypothesis, we extend Basu's regression model by including variable post $t_{i t}$ as follows: 
AJAR

5,1

164

Figure 3.

Net income box plots in Basu's expanded regression model (second hypothesis)

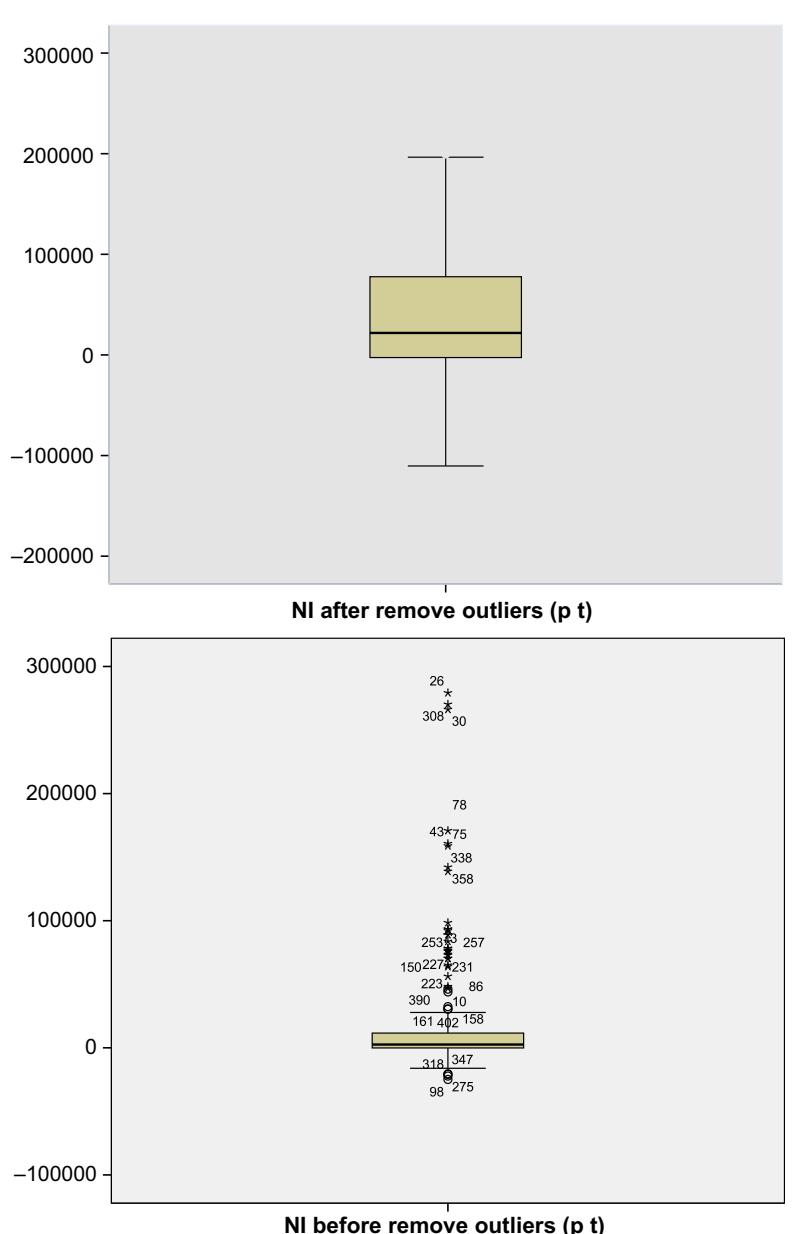

NI before remove outliers $(p t)$

$$
\begin{aligned}
\mathrm{NI}_{i t}= & \alpha_{0}+\alpha_{1} \mathrm{NEG}_{i t}+\alpha_{2} \mathrm{RET}_{i t}+\alpha_{3} \mathrm{RET}_{i t} \times \mathrm{NEG}_{i t}+\alpha_{4} \text { post }_{i t}+\alpha_{5} \mathrm{post}_{i t} \times \mathrm{NEG}_{i t} \\
& +\alpha_{6} \mathrm{post}_{i t} \times \mathrm{RET}_{i t}+\alpha_{7} \text { post }_{i t} \times \mathrm{RET}_{i t} \times \mathrm{NEG}_{i t}+\alpha_{8} \mathrm{MTB}_{i t-1} \\
& +\alpha_{9} \mathrm{MTB}_{i t-1} \times \mathrm{NEG}_{i t}+\alpha_{10} \mathrm{MTB}_{i t-1} \times \mathrm{RET}_{i t}+\alpha_{11} \mathrm{MTB}_{i t-1} \times \mathrm{RET}_{i t} \times \mathrm{NEG}_{i t} \\
& +\alpha_{12} \mathrm{LEV}_{i t-1}+\alpha_{13} \mathrm{LEV}_{i t-1} \times \mathrm{NEG}_{i t}+\alpha_{14} \mathrm{LEV}_{i t-1} \times \mathrm{RET}_{i t} \\
& +\alpha_{15} \mathrm{LEV}_{i t-1} \times \mathrm{RET}_{i t} \times \mathrm{NEG}_{i t}+\alpha_{16} \operatorname{size}_{i t-1}+\alpha_{17} \operatorname{siza}_{i t-1} \times \mathrm{NEG}_{i t} \\
& +\alpha_{18} \operatorname{size}_{i t-1} \times \mathrm{RET}_{i t}+\alpha_{19} \operatorname{size}_{i t-1} \times \mathrm{RET}_{i t} \times \mathrm{NEG}_{i t}+\alpha_{20} \mathrm{LIT}_{i t-1} \\
& +\alpha_{21} \mathrm{LIT}_{i t-1} \times \mathrm{NEG}_{i t}+\alpha_{22} \mathrm{LIT}_{i t-1} \times \mathrm{RET}_{i t}+\alpha_{23} \mathrm{LIT}_{i t-1} \times \mathrm{RET}_{i t} \times \mathrm{NEG}_{i t}+\varepsilon_{i t}
\end{aligned}
$$

Restating firms undertake higher conservatism during restatement years than prerestatement periods if $\alpha_{7}$ is nonnegative. Table 9 summarizes the results of final fitted model. 


\begin{tabular}{|c|c|c|c|c|c|c|}
\hline \multirow[b]{2}{*}{ Matched on } & $\begin{array}{r}\text { Unsta } \\
\text { re£ } \\
\text { coe }\end{array}$ & $\begin{array}{l}\text { The } \\
\text { dardized } \\
\text { ssion } \\
\text { cients }\end{array}$ & timated regression coeffic & & & \multirow[t]{2}{*}{$\begin{array}{l}\text { Capturing } \\
\text { differences in } \\
\text { conservatism }\end{array}$} \\
\hline & $B$ & Std. Error & $\begin{array}{c}\text { Standardized coefficient } \\
\text { Beta }\end{array}$ & $t$-Statistic & Sig & \\
\hline (Constant) & 0.066 & 0.201 & - & 0.328 & 0.743 & \\
\hline NEG_t $t$ & -0.048 & 0.220 & -0.125 & -0.219 & 0.827 & 165 \\
\hline $\mathrm{RET}_{-} t$ & $5^{-8.479}$ & 0.001 & -0.040 & -0.059 & 0.953 & \\
\hline RET_t$t$.NEG_ $t$ & 0.006 & 0.009 & 0.404 & 0.745 & 0.456 & \\
\hline TESTFIRM_ $t$ & -0.030 & 0.024 & -0.075 & -1.235 & 0.217 & \\
\hline TESTFIRM_ $t$.NEG_ $t$ & -0.013 & 0.035 & -0.027 & -0.375 & 0.708 & \\
\hline TESTFIRM_ $t$.RET $t$ & $5^{2.935}$ & 0.000 & 0.008 & 0.143 & 0.886 & \\
\hline TESTFIRM_ $t$.RET_ $t$.NEG_ $t$ & 0.452 & 0.179 & 0.339 & 2.525 & 0.012 & \\
\hline MTB_t_1 1 & 0.006 & 0.003 & 0.162 & 2.143 & 0.033 & \\
\hline MTB_t_1.NEG_t & -0.007 & 0.003 & -0.142 & -2.099 & 0.036 & \\
\hline MTB_t_1.RET_t & $7^{6.848}$ & 0.000 & 0.001 & 0.026 & 0.980 & \\
\hline MTB_t_1.RET_t $t$ NEG_ $t$ & -0.001 & 0.000 & -0.132 & -2.449 & 0.015 & \\
\hline LEV $t-1$ & -0.321 & 0.039 & -1.059 & -8.289 & 0.000 & \\
\hline LEV_t_1.NEG_t $t$ & 0.170 & 0.040 & 0.638 & 4.212 & 0.000 & \\
\hline LEV_t_1.RET_t $t$ & $5^{9.621}$ & 0.000 & 0.032 & 0.235 & 0.814 & \\
\hline LEV_t_ $1 . N E G \_t$ RETt_ $t$ & 0.006 & 0.003 & 0.309 & 2.350 & 0.019 & \\
\hline SIZE $t+1$ & 0.023 & 0.016 & 0.123 & 1.380 & 0.168 & \\
\hline SIZE_t_1.NEG_t & -0.010 & 0.018 & -0.319 & -0.575 & 0.566 & \\
\hline SIZE_t_1.RET_t_1 & $6^{-8.424}$ & 0.000 & -0.048 & -0.072 & 0.943 & \\
\hline SIZE_t_1_NEG_t_RET_t & -0.001 & 0.001 & -0.484 & -0.900 & 0.369 & \\
\hline LIT_t_t 1 & -0.787 & 0.720 & -0.078 & -1.093 & 0.275 & \\
\hline LIT_ $t \_1 . N E G \_t$ & 1.215 & 1.778 & 0.100 & 0.684 & 0.495 & \\
\hline LIT_t_1.RET_t $t$ & 0.007 & 0.013 & 0.030 & 0.546 & 0.586 & \\
\hline LIT_t$t$ 1.NEG_t.RET_t & 0.005 & 0.054 & 0.014 & 0.101 & 0.920 & \\
\hline \multicolumn{7}{|l|}{ Summary of regression models } \\
\hline Correlation coefficient & \multirow{2}{*}{\multicolumn{2}{|c|}{$\begin{array}{l}0.720 \\
0.518\end{array}$}} & $F$-statistic & \multicolumn{2}{|l|}{20.594} & Table 7. \\
\hline & & & $p$-value & \multicolumn{2}{|l|}{0.00} & Basu's expanded \\
\hline Regression coefficient & \multicolumn{2}{|c|}{0.452} & $t$-statistic & \multirow{2}{*}{\multicolumn{2}{|c|}{$\begin{array}{l}. .025 \\
0.012\end{array}$}} & regression panel model \\
\hline Durbin-Watson statistic & \multicolumn{2}{|c|}{1.693} & $p$-value & & & (second hypothesis) \\
\hline
\end{tabular}

It is noted that $R$ software has excluded $\mathrm{RET}_{i t}$ and $\mathrm{NEG}_{i t}$ from the model automatically due to the fact that there is a linear combination between these variables and the other variables used in the model. Indeed, the lower t-statistic of a given variable as compared to the margin of error of 0.05 is indicative of a linear combination between variables.

Based on the results shown in Table 9, the $t$-statistic for POST_t $\times R E T \_t \times N E G \_t$ is $2.128\left(t_{(0.95, n>30)}=1.96<2.128\right)$ and consequently the third hypothesis is also approved at the $95 \%$ confidence interval. More specifically, restating firms undertake higher conservatism during restatement years than prerestatement periods. Moreover, according to $R^{2}$ coefficient value, $42.3 \%$ of net income change is explained by the independent variables. Next, we test the third hypothesis using Khan-Watts' extended regression model by including the variable post $t_{i t}$ in our primary model. Using this model, we examine conservatism in restating firms during $t$ and $t$-1 periods. The extended model is presented as follows: 
AJAR

5,1

\begin{tabular}{|c|c|c|c|c|c|c|}
\hline & & coe & icients & Standardized coefficient & & \\
\hline & Matched on & $B$ & Std. Error & Beta & $t$-Statistic & Sig \\
\hline & (Constant) & 0.038 & 0.154 & - & 0.248 & 0.804 \\
\hline 166 & NEG_t & -0.163 & 0.185 & -0.424 & -0.881 & 0.379 \\
\hline & RET_ $t$ & $\begin{array}{r}0.000 \\
6.956\end{array}$ & 0.001 & -0.091 & -0.141 & 0.888 \\
\hline & & $\begin{array}{r}6^{6.956} \\
5^{-5.677}\end{array}$ & 0.000 & 0.040 & 0.065 & 0.948 \\
\hline & MTB_t $t \times$ RET_ $t$ & 5 & 0.000 & -0.158 & -2.647 & 0.008 \\
\hline & $\mathrm{LEV}_{-} t \times \mathrm{RET} \mathrm{R}_{-} t$ & 0.000 & 0.000 & 0.060 & 0.463 & 0.643 \\
\hline & LIT_t$+\times$ RETt_ $t$ & 0.001 & 0.005 & 0.037 & 0.263 & 0.792 \\
\hline & NEG $\_t \times$ RET $\_t$ & 0.002 & 0.008 & 0.110 & 0.223 & 0.824 \\
\hline & SIZE_ $t \times$ NEG_t $t \times$ RET $\_t$ & 0.000 & 0.001 & -0.239 & -0.490 & 0.625 \\
\hline & MTB $\_t \times$ NEG_t $t \times$ RET $\_t$ & 0.000 & 0.000 & -0.053 & -1.609 & 0.108 \\
\hline & LEV $\_t \times \mathrm{NEG}_{-} t \times \mathrm{RET}_{-} t$ & 0.005 & 0.002 & 0.272 & 2.828 & 0.005 \\
\hline & LIT $\_t \times$ NEG $\_t \times$ RET $\_t$ & 0.043 & 0.045 & 0.111 & 0.948 & 0.344 \\
\hline & $\mathrm{SIZ} \overline{\mathrm{E}} \_t$ & 0.023 & 0.012 & 0.111 & 1.828 & 0.068 \\
\hline & MTB_t $t$ & 0.021 & 0.005 & 0.594 & 4.398 & 0.000 \\
\hline & $\mathrm{LEV}_{-} \bar{t}$ & -0.336 & 0.032 & -1.230 & -10.653 & 0.000 \\
\hline & LIT_t $t$ & -0.014 & 0.085 & -0.023 & -0.168 & 0.867 \\
\hline & $\mathrm{NEG} \_t \times$ SIZE $\_t$ & 0.001 & 0.015 & 0.034 & 0.073 & 0.942 \\
\hline & $\mathrm{NEG}_{-}^{-} t \times \mathrm{MTB}_{-} t$ & -0.022 & 0.005 & -0.577 & -4.433 & 0.000 \\
\hline & $\mathrm{NEG} \_t \times \mathrm{LEV} \_t$ & 0.193 & 0.033 & 0.791 & 5.867 & 0.000 \\
\hline & NEG_t $t \times$ LIT_t $t$ & 1.653 & 1.424 & 0.136 & 1.161 & 0.246 \\
\hline & TESTFTIRM $\_t$ & -0.028 & 0.022 & -0.071 & -1.316 & 0.189 \\
\hline & TESTFIRM_ $\_$ $x$ NEG_ $t$ & -0.004 & 0.030 & -0.009 & -0.149 & 0.881 \\
\hline & TESTFIRM_ $t \times$ RET_ $t$ & $5^{1.416}$ & 0.000 & 0.004 & 0.084 & 0.933 \\
\hline & TESTFIRM $\_t \times$ RET $\_t \times$ NEG $\_t$ & 0.151 & 0.074 & 0.046 & 2.031 & 0.043 \\
\hline & Summary of regression models & & & & & \\
\hline Khan-Watts' & Correlation coefficient & & 782 & $F$-statistic & 30.45 & \\
\hline expanded regression & $R^{2}$ & & 611 & $p$-value & 0.00 & \\
\hline panel model (second & Regression coefficient & & 151 & $t$-statistic & 2.03 & \\
\hline hypothesis) & Durbin-Watson statistic & & 789 & $p$-value & 0.04 & \\
\hline
\end{tabular}

The estimated regression coefficients

Unstandardized regression

coefficients Standardized coefficient

Correlation coefficient

Regression coefficient

Durbin-Watson statistic

$$
\begin{aligned}
\mathrm{NI}_{i t}= & \alpha_{0}+\alpha_{1} \mathrm{NEG}_{i t}+\mu_{0} \mathrm{RET}_{i t}+\mu_{1} \operatorname{size}_{i t} \times \mathrm{RET}_{i t}+\mu_{2} \frac{M}{B_{i t}} \times \mathrm{RET}_{i t} \\
& +\mu_{3} \mathrm{LEV}_{i t} \times \mathrm{RET}_{i t}+\mu_{4} \mathrm{Lit}_{i t} \times \mathrm{RET}_{i t}++\lambda_{0} \mathrm{NEG}_{i t} \times \mathrm{RET}_{i t} \\
& +\lambda_{1} \operatorname{size}_{i t} \times \mathrm{NEG}_{i t} \times \mathrm{RET}_{i t}+\lambda_{2} \frac{M}{B_{i t}} \times \mathrm{NEG}_{i t} \times \mathrm{RET}_{i t} \\
& +\lambda_{3} \mathrm{LEV}_{i t} \times \mathrm{NEG}_{i t} \times \mathrm{RET}_{i t}+\lambda_{4} \mathrm{Lit}_{i t} \times \mathrm{NEG}_{i t} \times \mathrm{RET}_{i t}+\delta_{1} \operatorname{size}_{i t}+\delta_{2} \frac{M}{B_{i t}} \\
& +\delta_{3} \mathrm{LEV}_{i t}+\delta_{4} \mathrm{Lit}_{i t}+\delta_{5} \mathrm{NEG}_{i t} \times \operatorname{size}_{i t}+\delta_{6} \mathrm{NEG}_{i t} \times \frac{M}{B_{i t}}+\delta_{7} \mathrm{NEG}_{i t} \times \mathrm{LEV}_{i t} \\
& +\delta_{8} \mathrm{NEG}_{i t} \times \mathrm{Lit}_{i t}+\alpha_{4} \mathrm{POST}_{i t}+\alpha_{5} \mathrm{POST}_{i t} \times \mathrm{NEG}_{i t}+\alpha_{6} \mathrm{POST}_{i t} \times \mathrm{RET}_{i t} \\
& +\alpha_{7} \mathrm{POST}_{i t} \times \mathrm{RET}_{i t} \times \mathrm{NEG}_{i t}+\varepsilon_{i t}
\end{aligned}
$$

According to the results of fitted model shown in Table 10, the coefficient for $P O S T \_t \times R E T \_t \times N E G_{-} t$ is 1.893 and also its probability value is 0.009 (less than the 


\begin{tabular}{|c|c|c|c|c|c|c|}
\hline \multirow[b]{2}{*}{ Matched on } & $\begin{array}{r}\text { Unsta } \\
\text { reg } \\
\text { coe }\end{array}$ & $\begin{array}{l}\text { The } \\
\text { dardized } \\
\text { ssion } \\
\text { cients }\end{array}$ & timated regression coeffic & \multirow[b]{2}{*}{$t$-Statistic } & \multirow[b]{2}{*}{ Sig } & \multirow[t]{2}{*}{$\begin{array}{l}\text { Capturing } \\
\text { differences in } \\
\text { conservatism }\end{array}$} \\
\hline & $B$ & Std. Error & $\begin{array}{c}\text { Standardized coefficient } \\
\text { Beta }\end{array}$ & & & \\
\hline (Constant) & -0.066 & 0.316 & - & -0.210 & 0.834 & \\
\hline NEG_t $t$ & -1.111 & 0.597 & -3.096 & -1.860 & 0.064 & 167 \\
\hline $\mathrm{RET}_{-} t$ & 0.001 & 0.003 & 0.269 & 0.218 & 0.828 & \\
\hline $\mathrm{RET}_{-} t \times \mathrm{NEG} \_t_{-}$ & -0.017 & 0.018 & -1.437 & -0.996 & 0.321 & \\
\hline $\operatorname{POST} \_t$ & 0.027 & 0.033 & 0.076 & 0.814 & 0.417 & \\
\hline POST_t $t \times$ NEG_t $t$ & 0.068 & 0.061 & 0.164 & 1.118 & 0.265 & \\
\hline POST_ $t \times$ RET_ $t$ & $6^{-6.965}$ & 0.000 & -0.003 & -0.022 & 0.982 & \\
\hline $\mathrm{POST}_{-} t \times \mathrm{RET}_{-} t \times \mathrm{NEG} \_t$ & 0.259 & 0.122 & 0.118 & 2.128 & 0.034 & \\
\hline MTB_t$t \_1$ & 0.018 & 0.006 & 0.446 & 3.177 & 0.002 & \\
\hline MTB_t_ $1 \times$ NEG_t $t$ & -0.019 & 0.011 & -0.172 & -1.642 & 0.102 & \\
\hline MTB $t \_1 \times$ RET $\_t$ & $5^{-9.806}$ & 0.000 & -0.358 & -2.643 & 0.009 & \\
\hline MTB $\_t \_1 \times$ RET $_{-} t \times$ NEG $\_t$ & -0.002 & 0.001 & -0.317 & -2.242 & 0.026 & \\
\hline LEV_t_1 & -0.213 & 0.076 & -0.291 & -2.795 & 0.006 & \\
\hline LEV $\_t-1 \times N E G \_t$ & -0.190 & 0.120 & -0.427 & -1.579 & 0.116 & \\
\hline LEV $\_t \_1 \times \mathrm{RET}_{-} t$ & 0.000 & 0.001 & 0.094 & 0.265 & 0.791 & \\
\hline LEV $\_t \_1 \times$ NEG $\_t \times$ RET $\_t$ & -0.003 & 0.004 & -0.197 & -0.729 & 0.467 & \\
\hline SIZE_- 1 & 0.024 & 0.026 & 0.094 & 0.896 & 0.371 & \\
\hline SIZE_t_ $1 \times$ NEG_t $t$ & 0.093 & 0.049 & 3.128 & 1.908 & 0.058 & \\
\hline SIZE $\_t \_1 \times$ RET $t \_1$ & $5^{-6.217}$ & 0.000 & -0.362 & -0.299 & 0.765 & \\
\hline SIZE_t $t 1$ NEG_t $\times$ RET_ $t$ & 0.002 & 0.001 & 1.868 & 1.345 & 0.180 & \\
\hline LIT_t$t-\overline{1}$ & -0.033 & 0.491 & -0.086 & -0.067 & 0.947 & \\
\hline LIT_t $t=1 \times N E G \_t$ & -3.753 & 4.240 & -0.141 & -0.885 & 0.377 & \\
\hline LIT $t+1 \times$ RET $\_t$ & 0.001 & 0.019 & 0.077 & 0.059 & 0.953 & \\
\hline LIT_t $t=1 \times$ NEG $\_t \times$ RET $\_t$ & -0.118 & 0.154 & -0.126 & -0.766 & 0.445 & \\
\hline \multicolumn{7}{|l|}{ Summary of regression models } \\
\hline Correlation coefficient & \multicolumn{2}{|c|}{0.650} & $F$-statistic & \multicolumn{2}{|l|}{5.670} & \\
\hline$R^{2}$ & \multicolumn{2}{|c|}{0.423} & $p$-value & \multicolumn{2}{|l|}{0.00} & Basu's expanded \\
\hline Regression coefficient & \multirow{2}{*}{\multicolumn{2}{|c|}{$\begin{array}{l}0.259 \\
2.046\end{array}$}} & $t$-statistic & \multirow{2}{*}{\multicolumn{2}{|c|}{$\begin{array}{l}2.128 \\
0.034\end{array}$}} & regression panel model \\
\hline Durbin-Watson statistic & & & $p$-value & & & (third hypothesis) \\
\hline
\end{tabular}

significance level of 0.05). Therefore, the same as previous model, the third hypothesis is approved. In other words, restating firms undertake higher conservatism during restatement years $(t)$ than prerestatement periods $(t-1)$. Furthermore, according to $R^{2}$ coefficient value, $63.7 \%$ of net income change is explained by the independent variables.

\section{Conclusion}

The present study investigates the effectiveness of Basu (1997) and Khan and Watts' (2009) DT metrics in detecting predictable differences in conservatism following corrections of restated earnings. Since restatements are regarded as a public admission that previously issued financial statements are not in accordance with GAAP, earning restatements could indicate impaired financial reporting. Moreover, conservatism has been regarded as an important tool to constrain managers' ability to inflate earnings and improve the credibility of the accounting numbers. It consists of income recognition policies that result in recognizing bad news (economic losses) in a timelier fashion than recognizing good news (economic gains). In this regard, the most widely used measures of conservatism are Basu's (1997) DT coefficient and Khan-Watts' (2009) $C$-score. The effectiveness of these measures has been 
AJAR

5,1

\begin{tabular}{|c|c|c|c|c|c|c|}
\hline & Matched on & $\begin{array}{c}\text { regressio } \\
B\end{array}$ & $\begin{array}{l}\text { coefficients } \\
\text { Std. Error }\end{array}$ & $\begin{array}{c}\text { Standardized coefficient } \\
\text { Beta }\end{array}$ & $t$-Statistic & Sig \\
\hline & (Constant) & -0.148 & 0.271 & - & -0.547 & 0.585 \\
\hline & NEG_t & 0.099 & 0.277 & 0.226 & 0.357 & 0.721 \\
\hline 168 & $\mathrm{RET}_{-} t$ & -0.001 & 0.003 & -0.276 & -0.294 & 0.769 \\
\hline & $\mathrm{SIZE}_{-} t \times \mathrm{RET}_{-} t$ & $6^{-4.405}$ & 0.000 & -0.020 & -0.022 & 0.982 \\
\hline & $\mathrm{MTB}_{-} t \times \mathrm{RET}_{-}$ & $-5^{4.037}$ & 0.000 & 0.050 & 0.450 & 0.653 \\
\hline & $\mathrm{LEV}_{-}^{-} t \times \mathrm{RET}_{-}^{-} t$ & 0.001 & 0.001 & 0.233 & 1.182 & 0.238 \\
\hline & $\mathrm{LIT}_{-}^{-} t \times \mathrm{RET}_{-}^{-} t$ & 0.002 & 0.010 & 0.013 & 0.179 & 0.858 \\
\hline & $\mathrm{NEG}_{-} t \times \mathrm{RET}_{-} t$ & 0.001 & 0.008 & 0.063 & 0.114 & 0.910 \\
\hline & $\mathrm{SIZE}_{-} t \times \mathrm{NEG}_{-} t \times$ RET $\_t$ & 0.000 & 0.001 & -0.108 & -0.196 & 0.845 \\
\hline & MTB $\_t \times \mathrm{NEG}_{-} t \times \mathrm{RET}_{-} t$ & 0.000 & 0.000 & -0.060 & -1.363 & 0.174 \\
\hline & LEV $\_t \times N_{E G} \_t \times$ RET $\_t$ & 0.003 & 0.002 & 0.187 & 1.645 & 0.101 \\
\hline & LIT $\_t \times$ NEG_t $x \times$ RET $\_t$ & -0.118 & 0.105 & -0.050 & -1.125 & 0.262 \\
\hline & $\mathrm{SIZE} \_t$ & 0.044 & 0.022 & 0.330 & 1.985 & 0.048 \\
\hline & MTB_t & 0.018 & 0.007 & 0.510 & 2.561 & 0.011 \\
\hline & $\mathrm{LEV}_{-} t$ & -0.475 & 0.064 & -2.212 & -7.379 & 0.000 \\
\hline & $\mathrm{LIT}_{-} t$ & 0.775 & 1.448 & 0.034 & 0.535 & 0.5930 \\
\hline & $\mathrm{NEG}_{-} t \times \mathrm{SIZE} \_t$ & -0.029 & 0.022 & -0.786 & -1.278 & 0.202 \\
\hline & $\mathrm{NEG} \__{-} t \times \mathrm{MTB} \_t$ & -0.018 & 0.007 & -0.503 & -2.557 & 0.011 \\
\hline & $\mathrm{NEG}_{-} t \times \mathrm{LEV} \_t$ & 0.344 & 0.065 & 1.753 & 5.304 & 0.000 \\
\hline & NEG_t$t \times$ LIT $\_t$ & 2.973 & 2.668 & 0.057 & 1.114 & 0.266 \\
\hline & POST $\_t$ & 0.009 & 0.030 & 0.020 & 0.293 & 0.770 \\
\hline & 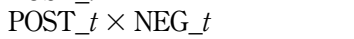 & -0.030 & 0.038 & -0.063 & -0.791 & 0.430 \\
\hline & $\mathrm{POST}_{-}^{-} t \times \mathrm{RET}_{-}-t$ & $5^{-9.963}$ & 0.000 & -0.027 & -0.396 & 0.692 \\
\hline & POST $t+x$ RET $\_t \times$ NEG $\_t$ & 1.893 & 0.721 & -0.013 & 2.626 & 0.009 \\
\hline Table 10. & Summary of regression models & & & & & \\
\hline Khan-Watts' & Correlation coefficient & & & $F$-statistic & 23.9 & \\
\hline expanded regression & $R^{2}$ & & & $p$-value & 0.0 & \\
\hline panel model (third & Regression coefficient & & & $t$-statistic & 2.6 & \\
\hline hypothesis) & Durbin-Watson statistic & & & $p$-value & 0.0 & \\
\hline
\end{tabular}

The estimated regression coefficients

Unstandardized

regression coefficients Standardized coefficient 
The findings of the present paper could be of interest to policymakers and standard setters of accounting who attempt to enhance neutrality as a prerequisite for high-quality and more desirable financial reports. This study identifies an economic unique context where the potential benefits of conservative reporting outweigh the costs of conservatism. In particular, this study attempts to highlight the role of conservatism in mitigating agency conflicts and information asymmetry and address the importance of conservatism in financial reporting process.

This study may provide many opportunities for future researches. Firstly, to our knowledge, very few studies have carefully investigated the demands for conservative reporting from regulators and policymakers' viewpoint. This can be highlighted in the light of recent FASB and IASB requirements in which conservatism has been excluded from the joint conceptual framework for financial reporting. Secondly, although some studies provide consistent evidence regarding the impact of managerial overconfidence on conservatism (e.g. Ahmed and Duellman, 2011), the empirical evidence on other managerial characteristics (e.g. accounting knowledge and management tenure) as well as audit firm characteristics is still lacking. Finally, there is a narrow line of research investigating the relationship between conservatism and acquisition efficiency and risk. In this regard, the effect of conservatism as an important property of corporate financial reporting on other types of investment can be understood as a research gap and thus deserves further exploration.

\section{Notes}

1. General Accountability Office.

2. Available at: http://www.codal.ir

3. To observe comparability of our sample data and also the fact that the fiscal year is identical to the solar calendar year (i.e. March 20th or its equivalent, Esfand 29th) for about $90 \%$ of publicly traded companies in the TSE, we have excluded firms with fiscal year not ending on March 20th.

4. All tests are conducted in $R$ statistical software.

\section{References}

Aghaei, M.A., Anvari Rostami, A., Zalaghi, H. and Etemadi, H. (2013), "The role of external auditors in voluntary vs forced financial restatements and its impact on earning quality before and after", Audit Science, Vol. 13 No. 12, pp. 101-121.

Ahmed, A.S. and Duellman, S. (2007), "Accounting conservatism and board of director characteristics: an empirical analysis", Journal of Accounting and Economics, Vol. 43 Nos 2-3, pp. 411-437.

Ahmed, A.S. and Duellman, S. (2011), "Evidence on the role of accounting conservatism in monitoring managers' investment decisions", Accounting and Finance, Vol. 51 No. 3, pp. 609-633.

Ahmed, A.S., Morton, R.M. and Schaefer, T.F. (2000), "Accounting conservatism and the valuation of accounting numbers: evidence of the Feltham-Ohlson (1996) model", Journal of Accounting, Auditing \& Finance, Vol. 15 No. 3, pp. 271-292.

Aier, J.K., Comprix, J., Gunlock, M.T. and Deanna, L. (2005), "The financial expertise of CFOs and accounting restatements", Accounting Horizons, Vol. 19 No. 3, pp. 123-135.

Ball, R. (2009), "Market and political/regulatory perspectives on the recent accounting scandals", Journal of Accounting Research, Vol. 47 No. 2, pp. 277-323.

Ball, R., Kothari, S.P. and Nikolaev, V. (2011), "On estimating conditional conservatism”, Working Paper, University of Chicago and the Massachusetts Institute of Technology.

Ball, R. and Shivakumar, L. (2005), "Earnings quality in UK private firms: comparative loss recognition timeliness", Journal of Accounting and Economics, Vol. 39 No. 1, pp. 83-128.

Basu, S. (1997), "The conservatism principle and the asymmetric timeliness of earnings", Journal of Accounting and Economics, Vol. 24 No. 1, pp. 3-37. 
AJAR

5,1

Beaver, W. and Ryan, S. (2000), "Biases and lags in book value and their effects on the ability of the book-to-market ratio to predict book return on equity", Journal of Accounting Research, Vol. 38 No. 1, pp. 127-148.

Beekes, W., Pope, P. and Young, S. (2004), "The link between earnings timeliness, earnings conservatism and board composition: evidence from the UK", Corporate Governance: An International Review, Vol. 12 No. 1, pp. 47-59.

Bagherpour, M.A., Monroe, G.S. and Shailer, G. (2014), "Government and managerial influence on auditor switching under partial privatization”, Journal of Accounting and Public Policy, Vol. 33 No. 4, pp. 372-390.

Bushman, R.M., Piotroski, J.D. and Smith, A.J. (2011), "Capital allocation and timely accounting recognition of economic losses", Journal of Business Finance and Accounting, Vol. 38 Nos 1-2, pp. 1-33.

Cao, Y., Myers, L.A. and Omer, T.C. (2012), "Does company reputation matter for financial reporting quality? Evidence from restatements", Contemporary Accounting Research, Vol. 29 No. 3, pp. 956-990.

Caskey, J. and Laux, V. (2016), “Corporate governance, accounting conservatism, and manipulation”, Management Science, Vol. 63 No. 2, pp. 424-437.

Chang, C.C., Lin, C.J. and Wang, V.S. (2011), "Do firms adopt more conservative earnings reporting strategies after restatements?” Working Paper.

Chen, K.Y., Elder, R.J. and Hung, S. (2014). "Do post-restatement firms care about financial credibility? evidence from the pre-and post-SOX Eras", Journal of Accounting and Public Policy, Vol. 33 No. 2, pp. 107-126.

Chin, C.L. and Chi, H.Y. (2009), "Reducing restatements with increased industry expertise", Contemporary Accounting Research, Vol. 26 No. 3, pp. 729-765.

Davani, G. (2003), Stock Exchange: Shares and Shares Assessment, Nashr Ney, Tehran.

Dechow, P.M. and Skinner, D.J. (2000), "Earnings management: reconciling the views of accounting academics, practitioners, and regulators", Accounting Horizons, Vol. 14 No. 2, pp. 235-250.

Defond, M.L. and Jiambalvo, J. (1991), "Incidence and circumstances of accounting errors", Accounting Review, Vol. 66 No. 3, pp. 643-655.

Desai, H., Hogan, C.E. and Wilkins, M.S. (2006), "The reputational penalty for aggressive accounting: earnings restatements and management turnover", Accounting Review, Vol. 81 No. 1, pp. 83-112.

Dietrich, R., Muller, K. and Riedl, E. (2007), "Asymmetric Timeliness Tests of Accounting Conservatism”, Review of Accounting Studies, Vol. 12 No. 1, pp. 95-124.

Dzinkowski, R. (2007), "What's keeping corporate controllers up at night?", Strategic Finance, Vol. 88 No. 8, pp. 34-39.

El-habashy, H.A. (2019), "The effect of corporate governance attributes on accounting conservatism in Egypt”, Academy of Accounting and Financial Studies Journal, Vol. 23 No. 3, pp. 1-18.

Ettredge, M., Huang, Y. and Zhang, W. (2009), "Restatement disclosures and subsequent accounting conservatism", Working Paper, Conference of the American Accounting Association (AAA), University of Kansas, Kansas.

Ettredge, M., Huang, Y. and Zhang, W. (2012), "Earnings restatements and differential timeliness of accounting conservatism", Journal of Accounting and Economics, Vol. 53 No. 3, pp. 489-503.

Ettredge, M., Huang, Y. and Zhang, W. (2013), "Restatement disclosures and management earnings forecasts”, Accounting Horizon, Vol. 27 No. 2, pp. 347-369.

Feltham, G.A. and Ohlson, J.A., (1995), "Valuation and clean surplus accounting for operating and financing activities", Contemporary Accounting Research, Vol. 11 No. 2, pp. 689-731. 
Francis, J.R. and Martin, X. (2010), "Acquisition profitability and timely loss recognition", Journal of Accounting and Economics, Vol. 49 Nos 1-2, pp. 161-178.

García-Teruel, P.J., Martínez-Solano, P. and Sánchez-Ballesta, J.P. (2014), "The role of accruals quality in the access to bank debt”, Journal of Banking and Finance, Vol. 38 No. 3, pp. 186-193.

General Accounting Office (GAO) (2002), Financial Statement Restatements: Trends, Market Impacts, Regulatory Reponses, and Remaining Challenges, GAO-03-138, Washington, DC.

Ge, W. and McVay, S. (2005), "The disclosure of material weaknesses in internal control after the sarbanes-oxley act", Accounting Horizons, Vol. 19 No. 3, pp. 137-158.

Givoly, D. and Hayn, C. (2000), "The changing time-series properties of earnings, cash flows and accruals: has financial reporting become more conservative?", Journal of Accounting and Economics, Vol. 29 No. 3, pp. 287-320.

Givoly, D., Hayn, C.K. and Natarajan, A. (2007), "Measuring reporting conservatism", Accounting Review, Vol. 82 No. 1, pp. 65-106.

Ghosh, A.A. and Moon, D. (2010), “Corporate debt financing and earnings quality”, Journal of Business Finance and Accounting, Vol. 37 Nos 5-6, pp. 538-559.

Ha, J. and Feng, M. (2018), "Conditional conservatism and labor investment efficiency", Journal of Contemporary Accounting and Economics, Vol. 14 No. 2, pp. 143-163.

Hay, L. and Sandefur, G. (2007), "Financial restatements: the changing rules of the game", Accounting \& Tax Periodicals, Vol. 16 No. 3, pp. 18-32.

Hirschey, M., Palmrose, Z.V. and Scholz, S. (2003), "Long-term market under-reaction to accounting restatements", Working Paper, University of Kansas, Lawrence, KS.

Hribar, P. and Jenkins, N.T. (2004), "The effect of accounting restatements on earnings revisions and the estimated cost of capital", Review of Accounting Studies, Vol. 9 Nos 2-3, pp. 337-356.

Huang, Y. and Zhang, W. (2009), "Earnings restatements and subsequent accounting conservatism", Aaa 2009 Financial Accounting And Reporting Section (Fars) Paper, available at: http://ssrn. com/abstract $=1267240$ or http://dx.doi.org/10.2139/ssrn.1267240.

Jaggi, B., Ng, A.C. and Xin, H.C. (2015), "Meet/beat market expectation, accounting conservatism and corporate governance", Accounting Conservatism and Corporate Governance, (accessed 11 December 2014).

Joos, P. and Lang, M. (1994), "The effects of accounting diversity: evidence from the European Union", Journal of Accounting Research, Vol. 32, pp. 141-168.

Khan, M. and Watts, R.L. (2009), "Estimation and empirical properties of a firm-year measure of accounting conservatism", Journal of Accounting and Economics, Vol. 48 Nos 2-3, pp. 132-150.

Kim, J.B., Lopatta, K. and Canitz, F. (2018), "Restatement likelihood and accounting conservatism: evidence from CFO style", SSRN 3132027.

Kinney, W.R. and McDaniel, L.S. (1989), "Characteristics of firms correcting previously reported quarterly earnings", Journal of Accounting and Economics, Vol. 11 No. 1, pp. 71-94.

LaFond, R. and Roychowdhury, S. (2008), "Managerial ownership and accounting conservatism", Journal of Accounting Research, Vol. 46 No. 1, pp. 101-135.

LaFond, R. and Watts, R. (2008), "The information role of conservative financial statements", Accounting Review, Vol. 83 No. 2, pp. 447-478.

Lagore, W. and Morton, R.M. (2009), "Do financial restatements lead to greater conservatism?", Working paper.

Lara, J.M.G., Osma, B.G. and Penalva, F. (2009), “Accounting conservatism and corporate governance”, Review of Accounting Studies, Vol. 14 No. 1, pp. 161-201.

Lara, J.M.G., Osma, B.G. and Penalva, F. (2016), "Accounting conservatism and firm investment efficiency”, Journal of Accounting and Economics, Vol. 61 No. 1, pp. 221-238.

differences in

conservatism 
AJAR

5,1

Laux, V. (2020), "Effects of accounting conservatism on investment efficiency and innovation", Journal of Accounting and Economics, Forthcoming, doi: 10.1016/j.jacceco.2020.101319.

Nasr, M.A. and Ntim, C.G. (2018), "Corporate governance mechanisms and accounting conservatism: evidence from Egypt", Corporate Governance: The International Journal of Business in Society, Vol. 18 No. 3, pp. 386-407.

Palmrose, Z.V. and Scholz, S. (2004), "The circumstances and legal consequences of non-GAAP reporting: evidence from restatements", Contemporary Accounting Research, Vol. 21 No. 1, pp. 139-180.

Palmrose, Z.-V., Richardson, V.J. and Scholz, S. (2004), "Determinants of market reactions to restatement announcement", Journal of Accounting and Economics, Vol. 37 No. 1, pp. 59-89.

Patatoukas, P.N. and Thomas, J.K. (2011), "More Evidence of Bias in the Differential Timeliness Measure of Conditional Conservatism”, Accounting Review, Vol. 86 No. 5, pp. 1765-1793.

Patel, F. and Zeckhauser, R. (1999), "Earnings management to exceed thresholds", Journal of Business, Vol. 72 No. 1, pp. 1-33.

Plumlee, M. and Yohn, T.L. (2010), "An analysis of the underlying causes attributed to restatements", Accounting Horizons, Vol. 24 No. 1, pp. 41-64.

Richardson, S., Tuna, I. and Wu, W. (2002), "Predicting earnings management: the case of earnings restatements", Working Paper, University of Pennsylvania, Michigan.

Saei, M.J., Bagherpour Valashani, M.A. and Mosavi Baaighi, S.N. (2013), "Restated financial statements: an empirical and descriptive study of the frequency and importance", The Iranian Journal of Financial Accounting Research, Vol. 5 No. 1, pp. 67-86.

Salehi, M., Farhangdoust, S. and Vahidnia, A. (2017), "Abnormal audit fees and future restatements: evidence from Tehran Stock Exchange", International Journal of Accounting, Auditing and Performance Evaluation, Vol. 13 No. 1, pp. 42-64.

Salehi, M., Timachi, M. and Farhangdoust, S. (2018), "Earnings quality and managerial access to debt financing: empirical evidence from Iran”, Journal of Economic and Administrative Sciences, Vol. 34 No. 1, pp. 48-70.

Srinivasan, S. (2005), "Consequences of financial reporting failure for outside directors: evidence from accounting restatements and audit committee members", Journal of Accounting Research, Vol. 43 No. 2, pp. 291-334.

Stober, T.L. (1996), "Do prices behave as if accounting book values are conservative? Crosssectional tests of the Feltham-Ohlson [1995] valuation model", Working Paper, University of Notre Dame.

Turner, L.E. and Weirich, R.R. (2006), "A closer look at financial statement restatements", CPA Journal, Vol. 76 No. 12, pp. 12-23.

Turner, L., Dietrich, J.R., Anderson, K. and Bailey, A.J. (2001), “Accounting restatements”, Working Paper, SEC and Ohio State University, Ohio.

Watts, R. (2003), "Conservatism in accounting Part One: explanations and implications", Accounting Horizons, Vol. 17 No. 3, pp. 207-221.

Watts, R. and Zimmerman, J. (1986), Positive Theory of Accounting, Prentice-Hall, Englewood-Cliffs, New Jersey, NJ.

Wilson, W.M. (2008), "An empirical analysis of the decline in the information content of earnings following restatements", Accounting Review, Vol. 83 No. 2, pp. 519-548.

Wu, M. (2002), "Earnings restatements: a capital market perspective", available at: http://ssrn.com/ abstract $=1844265$.

Xia, W. (2006), "Accounting restatements: A comparison between China and USA", Journal of Modern Accounting and Auditing, Vol. 2 No. 10, pp. 10-15.

$\mathrm{Xu}, \mathrm{X}$. (2009), "The changes of accounting conservatism around earnings restatements: an analysis of the impact of ceo compensation”, Doctoral Dissertation, Michigan State University, Michigan. 


\section{Further reading}

Ball, R. and Shivakumar, L. (2006), "The role of accruals in asymmetrically timely gain and loss recognition", Journal of Accounting Research, Vol. 44 No. 2, pp. 207-242.

Dichev, I. and Skinner, D. (2002), "Large sample evidence on the debt covenant hypothesis", Journal of Accounting Research, Vol. 40 No. 4, pp. 1091-1123.

Kothari, S.P., Shu, S. and Wysocki, P.D. (2009), "Do managers withhold bad news?", Journal of Accounting Research, Vol. 47 No. 1, pp. 241-276.
Capturing differences in conservatism

\section{Corresponding author}

Shayan Farhangdoust can be contacted at:Shayan_fd@yahoo.com

For instructions on how to order reprints of this article, please visit our website:

www.emeraldgrouppublishing.com/licensing/reprints.htm

Or contact us for further details: permissions@emeraldinsight.com 